\title{
Combining community approaches and government policy to reduce HIV risk in the Dominican Republic
}

\author{
Deanna Kerrigan \\ Luis Moreno \\ Bayardo Gomez \\ Hector Jerez \\ Ellen Weiss
}

See next page for additional authors

Follow this and additional works at: https://knowledgecommons.popcouncil.org/departments_sbsr-hiv

Part of the Demography, Population, and Ecology Commons, Gender and Sexuality Commons, Health Policy Commons, Immune System Diseases Commons, International Public Health Commons, Medicine and Health Commons, Place and Environment Commons, Public Health Education and Promotion Commons, and the Virus Diseases Commons How does access to this work benefit you? Let us know!

\section{Recommended Citation}

Kerrigan, Deanna, Luis Moreno, Bayardo Gomez, Hector Jerez, Ellen Weiss, Johannes van Dam, Eva Roca, Clare Barrington, and Michael D. Sweat. 2004. "Combining community approaches and government policy to reduce HIV risk in the Dominican Republic," Horizons Final Report. Washington, DC: Population Council. 


\section{Authors}

Deanna Kerrigan, Luis Moreno, Bayardo Gomez, Hector Jerez, Ellen Weiss, Johannes van Dam, Eva Roca, Clare Barrington, and Michael D. Sweat 
Combining Community Approaches and Government Policy to Prevent HIV Infection in the Dominican Republic

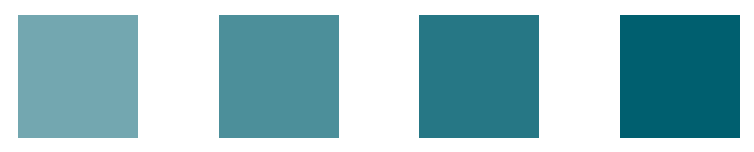

Horizons Program

Johns Hopkins University

Centro de Orientación e Investigación Integral Centro de Promoción y Solidaridad Humana International Center for Research on Women 


\title{
Combining Community Approaches and Government Policy to Prevent HIV Infection in the Dominican Republic
}

\author{
Deanna Kerrigan ${ }^{1}$, Luis Morenoㄹ, Santo Rosario², Bayardo Gomez ${ }^{3}$, \\ Hector Jerez ${ }^{3}$, Ellen Weiss ${ }^{4}$, Johannes van Dam ${ }^{5}$, Eva Roca ${ }^{6}$, \\ Clare Barrington ${ }^{7}$, and Michael Sweat ${ }^{7}$
}

\footnotetext{
${ }^{1}$ Horizons/J ohns Hopkins University

${ }^{2}$ Centro de Orientación e Investigación Integral (COIN)

${ }^{3}$ Centro de Promoción y Solidaridad Humana (CEPROSH)

${ }^{4}$ Horizons/International Center for Research on Women (ICRW)

${ }^{5}$ Horizons/Population Council

${ }^{6}$ ICRW, formerly Horizons/Population Council

${ }^{7}$ Johns Hopkins University
} 


\section{Acknowledgments}

The authors would like to thank the research participants for their time, insight, and dedication, as well as the members of local partner organizations that assisted with the research and the implementation of intervention activities. These include Martha Butler de Lister of the CONECTA Project of Family Health International (formerly of the Dirección General de Control de Enfermedades de Transmisión Sexual [DIGECITSS]); William Hernandez, Rosa Flores, Juliana Martinez, and Yafmari Feliz of DIGECITSS; Alexandra Lister, Nancy Gomez, Ramon Hipolito, Nila Fernandez, Carmen Hernandez, Belkis Altagracia de la Rosa, Juan Familia, Elisa Polanco, and Arelis Moore of the Centro de Promoción y Solidaridad Humana (CEPROSH); Francisca Ferreira, Juana Clase and Melchor Moya of the Centro de Orientación e Investigación Integral (COIN); Carmen Lorenzo, Marina Torres, and Marina Ureña of the Movimiento de Mujeres Unidas (MODEMU); Margarita Quiñones from the Instituto Dermatológico de Cirugia de la Piel (IDCP); the participating government health inspectors and their regional coordinators of the Dirección de Saneamiento Ambiental of the Ministry of Public Health; the participating clinicians from the public health clinics serving female sex workers and their regional coordinators of the Direcciones Provinciales de Salud of the Ministry of Public Health; and Tito Coleman of the AccionSIDA Project of the Academy for Educational Development (AED).

We would also like to thank the following persons who helped review and refine this report, including Carol Jenkins, an independent consultant and the former Near East Regional HIV advisor with the Asia Bureau of USAID; Jerry Jennings of USAID; Anneke van den Hoek, director of the Municipal Health Service of Amsterdam in the Netherlands; and Naomi Rutenberg, Lewis Ndhlovu, and Eka Esu-Williams of the Horizons Program. Finally, thanks to Andy Fisher, director of the Horizons Program/Population Council; Barbara de Zalduondo of Social and Scientific Systems (formerly of USAID); and David Stanton of USAID for their encouragement and support throughout the research process.
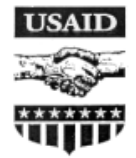

This study was supported by the Horizons Program, which is implemented by the Population Council in collaboration with the International Center for Research on Women, International HIV/AIDS Alliance, Program for Appropriate Technology in Health, Tulane University, Family Health International, and Johns Hopkins University. Horizons is funded by the U.S. Agency for International Development (USAID), under the terms of HRN-A-00-97-00012-00. The opinions expressed herein are those of the authors and do not necessarily reflect the views of USAID.

Published in March 2004.

\section{(2) Population Council}

The Population Council is an international, nonprofit, nongovernmental institution that seeks to improve the well-being and reproductive health of current and future generations around the world and to help achieve a humane, equitable, and sustainable balance between people and resources. The Council conducts biomedical, social science, and public health research and helps build research capacities in developing countries. Established in 1952, the Council is governed by an international board of trustees. Its New York headquarters supports a global network of regional and country offices.

Copyright (C) 2004 The Population Council Inc.

This document may be reproduced in whole or in part without permission of the Population Council provided full source citation is given and the reproduction is not for commercial purposes.

Suggested citation: Kerrigan, Deanna, Luis Moreno, Santo Rosario, Bayardo Gomez, Hector Jerez, Ellen Weiss, Johannes van Dam, Eva Roca, Clare Barrington, and Michael Sweat. 2004. "Combining Community Approaches and Government Policy to Prevent HIV Infection in the Dominican Republic," Horizons Final Report. Washington, D.C.: Population Council. 


\section{Table of Contents}

Executive Summary

Introduction 5

Thai 100 Percent Condom Program $\quad 6$

$\begin{array}{ll}\text { Adapting the Thai Program to the DR } & 6\end{array}$

Methods $\quad 8$

Research setting $\quad 8$

$\begin{array}{ll}\text { Study design } & 9\end{array}$

The intervention $\quad 9$

Data collection and ethical procedures 13

$\begin{array}{ll}\text { Measures } & 14\end{array}$

$\begin{array}{ll}\text { Data management and analysis } & 16\end{array}$

Results 17

$\begin{array}{ll}\text { Characteristics of the sample } & 17\end{array}$

Pre- to post-intervention changes in HIV-related risk 18

Other outcomes of the intervention $\quad 24$

$\begin{array}{ll}\text { Cost-effectiveness analysis } & 25\end{array}$

Results 33

$\begin{array}{ll}\text { Discussion } & 40\end{array}$

Limitations of the Research

$\begin{array}{ll}\text { Conclusions } & 44\end{array}$

$\begin{array}{ll}\text { References } & 45\end{array}$ 



\section{Executive Summary}

Effective programs that avert new HIV infections among sex workers and their partners, and hence the general population, are critical components of national HIV prevention strategies. Prevention efforts have frequently relied on interventions that reach members of these vulnerable groups as individuals, such as condom promotion and STI management. Now, many researchers and program implementers are increasingly turning to "environmental-structural" interventions that address the physical, social, and political contexts in which individual behavior takes place.

Two environmental-structural approaches have recently been shown to increase rates of condom use and decrease STI prevalence among female sex workers. One focuses on community development and mobilization to build a collective commitment to prevention, such as the Sonagachi Project in Calcutta, India (Jana 1998). The second involves government-sponsored initiatives, including the " 100 Percent Condom Program" in Thailand, that utilize a government policy mandating condom use in brothels (Rojanapithayakorn 1996).

A recent Horizons study conducted jointly with two Dominican NGOs-Centro de Orientación e Investigación Integral (COIN) and Centro de Promoción e Solidaridad Humana (CEPROSH) - and the National Program for the Control of STDs and AIDS (DIGECITSS) assessed the impact of two environmental-structural models in reducing HIV-related risk among female sex workers in the Dominican Republic and compared their cost-effectiveness. The models, built on years of experience gained from sex worker peer education programs, drew from the strengths of both community solidarity and government policy initiatives and engaged community members in both program and policy development.

\section{Description of the I ntervention}

The models, developed after extensive formative research and consultation with sex worker peer leaders, were implemented in 68 sex establishments in two Dominican cities. In Santo Domingo, the nation's capital, a community-based solidarity approach to 100 percent condom use was implemented, while in Puerto Plata, a smaller coastal city in the north where tourism is prevalent, solidarity was combined with government policy and regulation.

Solidarity-building activities included workshops and meetings with sex workers, sex establishment owners and managers, and other employees, such as doormen and deejays, to strengthen collective commitment to HIV/STI prevention, particularly in supporting sex workers to use condoms with partners. These gatherings also focused on exploring issues of trust and intimacy in condom use negotiation between sex workers and regular paying and non-paying partners.

To enhance a collective commitment to prevention, each sex establishment owner was encouraged to ensure that 100 percent condom use posters and other awareness-raising materials, as well as glass bowls filled with condoms, were in place within each establishment. Other cues to support 


\section{Hgrizons}

condom use included deejay messages about safer sex, information booths at establishment entrances, and participatory theater with male clients.

In Puerto Plata, the same model was used but included a government-sponsored policy that required condom use between sex workers and all clients. Owners were told that they, not the sex workers, were responsible for ensuring compliance with the policy and with program activities. For those not in compliance, government officials imposed a graduated series of warnings, fines, and other sanctions, including closure of the establishment.

\section{Methods}

Researchers used a pre-/post-test evaluation design to assess the two, year-long programs conducted in 34 sex establishments in each city. Structured surveys and non-routine STI testing were conducted among a random, cross-sectional sample of approximately 200 female sex workers, age 18 years and older, from the study establishments. Women were recruited at government health clinics in each city and data were collected at baseline and at the end of the 12-month intervention period.

In both cities, the median age of female sex workers who participated in the baseline was 25 years; the median number of years of schooling completed was seven. More than 75 percent were single, and nearly two-thirds had a regular partner. The median number of reported encounters with paying clients in the last week was two in Puerto Plata (range: 0-32) and one in Santo Domingo (range: 0$30)$.

Government health inspectors accompanied by NGO staff visited sex establishments in both cities on a monthly basis to assess compliance with five key elements: the presence of 100 percent condom use posters, availability of at least 100 condoms on site, visibility and accessibility of condoms for clients and sex workers, attendance of all of the establishment's sex workers at monthly STI check-ups, and a lack of a positive STI diagnosis among sex workers based at the establishment.

Participant observations were also conducted pre- and post-intervention among a random sample of 64 sex workers in each city, by male NGO staff members posing as clients. Following a strict research protocol, each NGO staffer selected a sex worker, talked with her at a table in the establishment, then asked if she would be willing to have sex without a condom, presenting up to four reasons, developed during formative research, why he did not want to use one.

The study was approved by the ethical review boards of the Population Council and Johns Hopkins University. DIGECITTS also reviewed the study for technical and ethical merit. 


\section{Key Findings}

Consistent condom use (CCU) rose significantly in each city, albeit with different types of clients. CCU with new clients in the last month increased significantly among sex workers in Santo Domingo, from 75 to 94 percent $(\mathrm{p}<.001)$. In Puerto Plata, where CCU with new clients was already high at 96 percent, the rate increased to 99 percent. Only in Puerto Plata did CCU rise significantly for regular paying and non-paying partners, from 13 to 29 percent ( $\mathrm{p}=.001)$; in Santo Domingo, CCU with regular partners rose only slightly, from 15 to 18 percent. These figures are particularly important given the much lower levels of pre-intervention condom use documented with regular paying and non-paying customers, com-pared to condom use with new clients. Addition-ally, the study found that the majority of sex acts in the last month among all respondents occurred with regular paying partners, making the increase in Puerto Plata particularly important.

Sex workers' ability to reject unsafe sex rose significantly only in Puerto Plata. Results from the participant observations showed that the percent of sex workers who rejected having sex without a condom after hearing all four reasons increased significantly from 50 to 79 percent $(\mathrm{p}<$ .001). In Santo Domingo, rejection of unsafe sex also increased from 64 to 72 percent, but the difference was not statistically significant.

Rates of STIs decreased almost 40 percent from pre- to post-intervention. As shown in Figure 1 , there were significant decreases in both cities in the proportion of women testing positive for one or more of three STIs (gonorrhea, trichomoniasis, and/or chlamydia), with slightly stronger declines documented in Puerto Plata $(\mathrm{p}=.003)$, compared to Santo Domingo $(\mathrm{p}=.014)$. These overall reductions were due largely to decreases in specific STIs: in Santo Domingo, the prevalence of chlamydia decreased significantly from 16 to 9 percent $(\mathrm{p}=.029)$, while in Puerto Plata, the prevalence of trichomoniasis decreased significantly from 10 to 4 percent $(\mathrm{p}=.024)$.

CCU among sex workers was associated with higher levels of exposure to the intervention and compliance with the intervention by their establishment. In multivariate analyses, the research team found that the odds of consistent condom use among sex workers with all their sexual partners in the last month was 1.84 (CI 1.07-3.17) times greater among those with higher levels of reported exposure to the intervention. CCU was also 2.33 (CI 1.01-5.39) times greater among sex workers from sex establishments with the highest level of observed compliance to key intervention elements.

Sex establishments participating in the intervention in Puerto Plata showed a significant increase in observed compliance with intervention elements. Although reported exposure to the intervention increased significantly among sex workers in both cities, levels of observed compliance with the five key intervention elements increased significantly, from an average of 2.6 at month one to 4.7 at month twelve $(\mathrm{p}<.001)$, only at establishments in Puerto Plata, where a government policy mandating condom use and a graduated sanction system for non-compliance were implemented. 


\section{Hgrizons}

The Puerto Plata model, which includes government regulation, is more cost-effective than the Santo Domingo model. A cost analysis done by the researchers shows that while the cost to implement the two models is comparable, the combined intervention model that includes government regulation and oversight is approximately two and a half times more cost-effective. The cost per HIV infection averted in Puerto Plata, at $\$ 9,843$, is substantially less than in Santo Domingo, at $\$ 25,574$. When converted, the cost per disability adjusted life years (DALY) saved is \$414 in Puerto Plata, compared to \$1,075 in Santo Domingo.

\section{Conclusions}

In both cities there were improvements from pre-to post-intervention in the study's key outcome variables: consistent condom use, rejection of unsafe sex, and STI prevalence. Yet the type and level of these changes varied by intervention approach. The Puerto Plata model, which included a government policy and enforcement component, appears to have been more successful in bringing about significant increases in CCU with regular partners. Similarly, the ability of sex workers to reject unsafe sex rose significantly only in Puerto Plata.

The triangulation of findings shows that while both models had a positive impact on reducing vulnerability to HIV, the impact of the intervention appears to have been broader in Puerto Plata. Cost-effectiveness data also show that the Puerto Plata model is much more cost-effective than the Santo Domingo model. These gains in Puerto Plata are likely linked to the ability of that city's combined model - community solidarity plus government policy and enforcement - to achieve higher levels of compliance with key intervention elements compared to Santo Domingo.

While there are some limitations to the study (e.g., pre/post design, only one model implemented per city), triangulation of data from different sources highlights that the combined solidarity- and policy-based model is a feasible, acceptable, and effective intervention package for the Dominican Republic. With funding from the Global Fund, the World Bank, and USAID, the implementing NGOs in coordination with the Dominican government are currently scaling up the combined model in areas of the country where commercial sex is prevalent. 


\section{Introduction}

Because of multiple sexual partners, female sex workers, especially those from disadvantaged socioeconomic settings, are particularly vulnerable to HIV infection and other sexually transmitted infections (STIs) (Gysels et al. 2002; Ghys et al. 2001; Kalipeni 2000; Campbell 2000; Gray et al. 1997; Aklilu et al. 2001). Epidemiological studies from many countries have documented significantly higher rates of HIV infection among female sex workers, compared to other population groups within the same geographic area and cultural context (Asamoah-Adu et al. 2001; Quan et al. 2000; Mehendale et al. 1995).

For example, according to a recent Demographic Health Survey within which oral HIV testing was conducted with 15- to 49-year-old males and females across the Dominican Republic, HIV prevalence in the general population is estimated at 1.0 percent (CESDEM 2003). However, national HIV prevalence among female sex workers is approximately 7 percent, with infection rates reaching as high as 12 percent in some regions of the country (SESPAS 2000). Although the Dominican Republic is a relatively small country of approximately 8.4 million people, the number of female sex workers has been conservatively estimated at 60,000 to 100,000, indicating that a substantial number of women are at increased risk for HIV infection because of multiple sex partners (AIDSCAP 1993; COIN 2000).

Sex workers are thus an important target group for HIV prevention programs, which aim to safeguard their health and also avert thousands of potential new infections among the general population. Such programs have frequently relied upon individual-level interventions, such as peer education, condom promotion and distribution, and STI management. Several programs in developing country settings have demonstrated increased rates of condom use or reductions in STIs among female sex workers using one or more of these approaches (Laga et al. 1994; Bhave et al. 1995; Ngugi et al. 1996; Ford et al. 1996).

But new perspectives and approaches are informing sex work program design. Over time, a consensus has emerged in public health that changing high-risk behavior and reducing HIV vulnerability does not occur in a vacuum but rather is the product of many individual, relational, sociocultural, environmental-structural, and technological processes and forces (Sweat and Denison 1995; Tawil et al. 1995; O’Reilly and Piot 1996; Aggleton 1997; Merson et al. 2000; Parker et al. 2000; Auerbach and Coates 2000; Waldo and Coates 2000). In response, HIV prevention programs are increasingly focusing attention on "environmental-structural" sex work interventions that seek to address these broader contexts (Sweat and Denison 1995; Sumartojo 2000). Additional prevention strategies have in turn been developed (UNAIDS 2002; Moreno and Kerrigan 2000), including capacity building, skills development, and community mobilization of female sex workers (Jana et al. 1998; Campbell et al. 2001; Evans 1999; Busza and Schunter 2001); increased involvement of key stakeholders, such as sex establishment owners and managers (Visrutaratna et al. 1995; Sakondhavat et al. 1997; Morisky et al. 1998; Morisky et al. 2002); and educational activities with male clients (Leonard et al. 2000). 


\section{Hgrizons}

\section{Thai 100 Percent Condom Program}

Such efforts gained considerable attention as a result of the government-sponsored Thai 100 Percent Condom Program, which required that condoms be used in all brothel-based sex acts (Rojanapithayakorn and Hanenberg 1996). The program also included free access to condoms in sex establishments, monthly screening and management of STIs among female sex workers, and a national media campaign directed at male clients of sex workers. Sex establishment owners not complying with the policy were subject to such sanctions as fines and closings.

Evaluation data from the Thai government demonstrate significant increases in reported condom use among female sex workers and their clients and significant decreases in the rates of STIs among men who frequented participating sex establishments during the period 1989 to 1993 (Hanenberg et al. 1994). Subsequent research has confirmed a decline in HIV incidence among Thai military recruits who reported visiting sex establishments and who received targeted educational activities (Mason et al. 1995; Nelson et al. 1996; Celentano et al. 1998; Nelson et al. 2002).

Recent discourse in the literature has raised concerns about the level of community participation in the Thai 100 Percent Condom Program as well as its transferability to other settings (Kilmarx et al. 1998; Evans 1999; Parker et al. 2000). Although several programs and countries have sought to adopt a regulatory approach similar to the Thai program to prevent HIV/STIs among female sex workers and their partners (UNAIDS 2002) efforts to increase community participation in program development and implementation have been more limited.

\section{Adapting the Thai Program to the DR}

For many years, two Dominican NGOs, Centro de Orientación e Investigación Integral (COIN) and Centro de Promoción y Solidaridad Humana (CEPROSH) had implemented peer education, condom distribution, improved STI management, and community mobilization and empowerment strategies to prevent HIV/STIs among sex workers and their clients. Using these approaches, consistent condom use with new clients rose significantly in intervention areas in both cities over the last decade.

However, rates of consistent condom use with regular paying and non-paying partners have remained relatively stable and significantly lower than with new clients (Rosario et al. 1994; CESDEM 1996; CESDEM 1999). Qualitative research conducted in Santo Domingo reveals that many sex workers reported that their regular paying and non-paying partnerships place them at increased risk for HIV/STIs because they are less likely to use condoms with partners of trust (parejas de confianza) (Kerrigan et al. 2001). This finding suggests that female sex workers may need greater support and motivation to negotiate condom use in these relationships than prior intervention approaches have provided.

In the mid-1990s, COIN and CEPROSH began to explore the adaptation of the Thai program to the Dominican context, including a greater emphasis on community mobilization. Formative 
ethnographic research conducted in Santo Domingo with sex workers and their partners, sex establishment owners and managers, and government officials documented significant support for government policies and support systems to promote and monitor the use of condoms in sex establishments (Kerrigan et al. 2001). This formative study also revealed ways in which sex workers, owners, managers, and other establishment employees assist and support sex workers in condom negotations with clients and that several sex establishments had already developed their own institutional condom use policies (Kerrigan et al. 2001). These findings confirmed the need to go beyond the original Thai model of government-sponsored policies and activities to include more participatory and community-based strategies to create an environment that fosters condom use in sex establishments.

Then, in collaboration with the Dominican government, Johns Hopkins University, and the Horizons Program, the two NGOs developed and tested two approaches to promote 100 percent condom use in sex establishments: (1) a community-based solidarity model and (2) a communitybased solidarity model plus government policy and regulation. The resulting research examined the impact of these two approaches on HIV-related risk among female sex workers. 


\section{Hgrizons}

\section{Methods}

\section{Research Setting}

Commercial sex or the act of exchanging sex for money is not illegal in the Dominican Republic, as long as the sex worker is not under the age of 18. Since there is no law explicitly prohibiting commercial sex in the Dominican Republic, neither sex workers nor their clients are generally prosecuted by law enforcement officials. However, discrimination and harassment of sex workers, especially those based on the street, has been documented in the past.

Female sex workers and their clients are found throughout the country and are particularly prevalent in such urban areas as Santo Domingo and in such tourist areas as Puerto Plata. An estimated 80 percent of women work out of sex or entertainment establishments, including brothels, bars, discos, and cabarets (Pareja and Rosario 1992), while the remainder are based outside on the street, in parks, or in other areas.

There are two general types of sex establishments in the Dominican Republic: direct and indirect. Direct sex establishments are older and more traditional, such as a brothel or casa de cita. Men typically come to a brothel explicitly in search of a woman with whom to have sex. There are always beds on the premises, although sex may also occur outside the establishment in a motel. In direct establishments, the women's' only source of income is typically what they earn from having sex with clients. Currently, brothels make up a small percentage of the establishment-based sex industry in the Dominican Republic. For example, in Santo Domingo only about 10 percent of all sex establishments are brothels (COIN 1998). Brothels are typically more expensive and exclusive than other types of sex establishments and are usually frequented by men of higher socioeconomic status.

Indirect sex establishments are the most common type of sex establishment in the country; in Santo Domingo, 90 percent of all sex establishments are indirect (COIN 1998). What distinguishes them from direct establishments is that they employ women to provide a service other than sex, such as waitressing or dancing (Kerrigan et al. 2001). Examples of indirect establishments include bars, discos, and nude dancing clubs. Indirect establishments do not often have beds and seldom have sex workers living on the premises. Sex with clients usually takes place in motels close to the establishment.

In the case of both direct and indirect sex establishments, a set fee (salida) is paid by the client to the establishment owner to have sex with a woman who works there. The woman then negotiates her own price with the client and keeps this money for herself. Other more informal entertainment establishments also exist, where salidas are not paid to the house but where women leave with men to have sex. However, the focus of the current intervention study was on establishments where salidas are paid to the house. 


\section{Study Design}

A pre-test/post-test evaluation design was used to evaluate the impact of two models to promote 100 percent condom use implemented over the course of one year in 34 female sex establishments in Santo Domingo and Puerto Plata. The pre-post evaluation design was supported by crosssectional data collected on a monthly basis from each participating sex establishment on its level of compliance with intervention activities. The two cities selected to participate in the study were chosen based on a number of criteria:

- The commitment of policymakers to support the intervention trial.

- The technical expertise of the NGOs to carry out intervention activities.

- The existence of a large number of sex establishments.

- The availability of a viable public STI management and monitoring system.

Within each city, the researchers purposively selected geographic areas where commercial sex was most prevalent, as determined by census data collected by the NGOs, to implement intervention activities. Selection criteria for participating sex establishments included having more than five women working on the premises and being a place where a salida or fee is paid by the client to the establishment. These criteria allowed for the inclusion of both direct and indirect sex establishments. All sex establishments that met the site selection criteria within the established geographic areas were invited to participate, and all agreed.

\section{The I ntervention}

The two models that promote 100 percent condom use were developed after extensive qualitative and quantitative research, and in consultation with sex worker peer leaders and members of the local sex worker organization, MODEMU. The model implemented in Santo Domingo involved a community-based approach that focused on building solidarity among sex workers, sex establishment owners, and other members of the sex work community, while the model implemented in Puerto Plata combined this approach with a regional government policy requiring condom use in all participating sex establishments. Both models were standardized in the two cities for the intervention trial.

Both models take into account environmental-structural theory, which posits that individual behavior change is facilitated or constrained by the physical, social, and political environment in which the realm of choice is defined and decisions are made (Sweat and Denison 1995). In the case of HIV prevention, sex workers are often the lone actors responsible and accountable for risk reduction without regard to gender- and class-based power imbalances between them, their clients, and establishment owners and managers. Interventions based on environmental-structural theory seek to create an environment in which not only sex workers but all members of the female sex industry are mutually responsible for preventing HIV/STIs.

Both NGOs and government agencies implemented the intervention activities. COIN in Santo Domingo and CEPROSH in Puerto Plata led the research and solidarity-building and educational 


\section{Hgrizons}

efforts in each city, in collaboration with MODEMU. The National AIDS Control Program, Dirección General para el Control de las Infecciones de Transmision Sexual y SIDA (DIGECITSS) and the Regional Health Department of Puerto Plata played key roles in developing and implementing the 100 percent condom policy implemented in Puerto Plata. The Instituto Dermatológico y Cirugia de la Piel and several other public STI clinics conducted periodic STI screening and biomedical analysis as part of evaluation activities. Both the national and local branches of the Dominican Department of Environmental Health assisted in the evaluation of the project. International donors, universities, and agencies, such as the Horizons Program, the Johns Hopkins Bloomberg School of Public Health, the AcciónSIDA Project of the Academy for Educational Development, USAID/Washington, and USAID/Dominican Republic, provided financial and technical support for the intervention and the research.

The following sections describe the key intervention activities that were implemented in both cities.

\section{Building solidarity and collective commitment}

The project team undertook a variety of activities to build solidarity among female sex workers, sex establishment owners/managers, and other establishment employees, and to develop a collective commitment to 100 percent condom use by sex workers and their clients. These efforts included participatory workshops that highlighted the role of each individual in helping and supporting female sex workers to negotiate condom use with their sexual partners. These workshops were held with each of the three key groups and included participants from different sex establishments. In total, four quarterly workshops were conducted with each group during the course of the one-year intervention period.

All workshop participants were asked to sign a social contract pledging their commitment to promote health and wellbeing within the establishment. Group-specific educational materials were developed to reinforce the idea of collective commitment and highlight the rights and responsibilities of each group in helping to protect each other's health and wellbeing.

An additional focus of the workshops was the role of trust and intimacy among sex workers and regular paying and non-paying partners and its effect on condom use and HIV risk. Formative research revealed that a continuum of sexual partner types exist for many female sex workers, rather than a strict dichotomy of client as opposed to non-paying boyfriend or husband

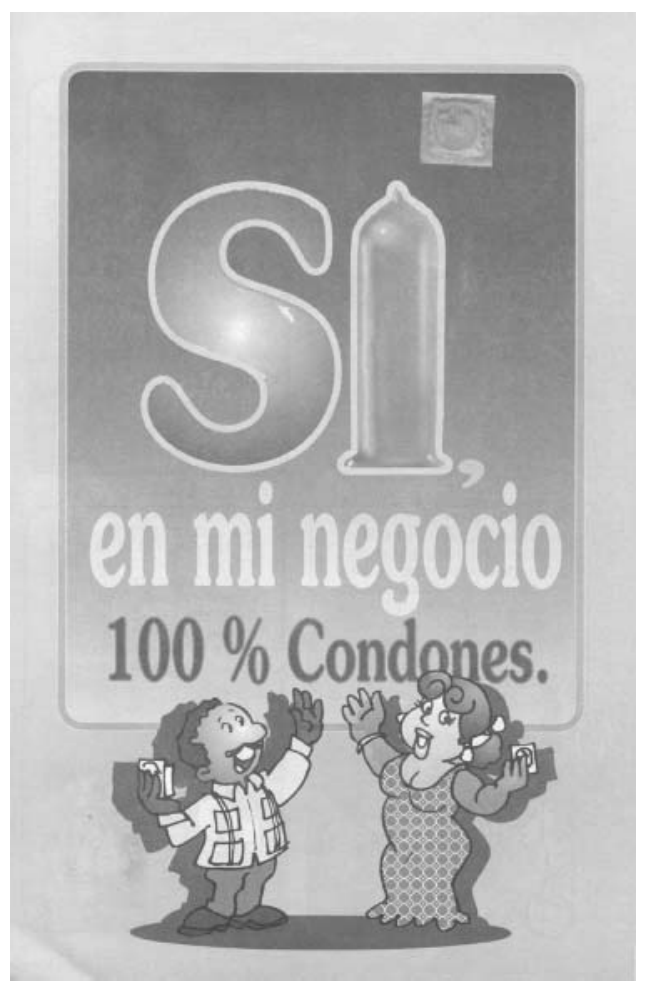


(Kerrigan et al. 2001). During the workshops, interactive games helped the women describe and define the different types of relationships they had with their sexual partners and together identify the HIV/STI risks for each kind of relationship. As a group, the women brainstormed how they could be more critical and objective in establishing relationships of trust and participated in role plays to develop communication and negotiation techniques they could use to ensure safer sex with different partner types. Specific educational messages and materials were developed for these purposes.

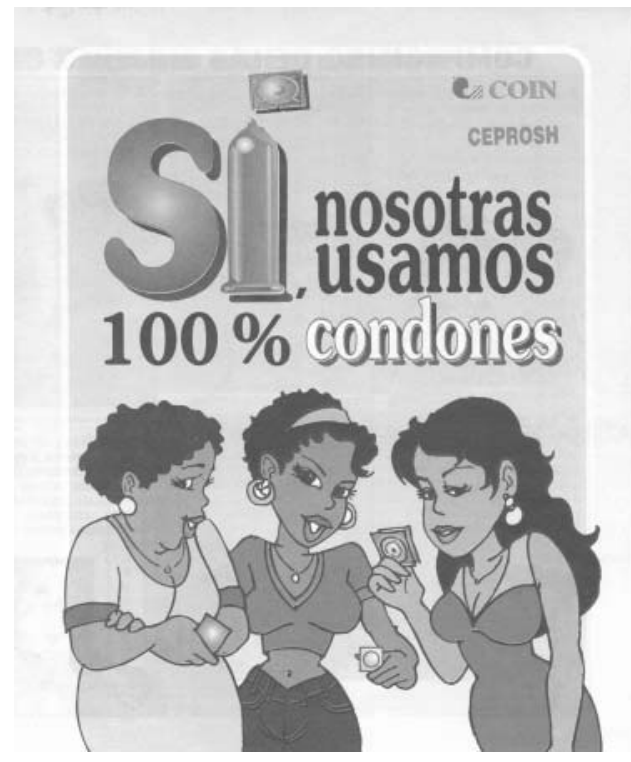

The final workshop encouraged participants to discuss their experiences with intervention activities and to provide feedback. Monthly meetings were also held in each establishment to assess progress and discuss ways to overcome barriers to achieving the principles of collective commitment to condom use. Both the quarterly workshops and monthly meetings were facilitated by a combination of NGO staff members and sex worker peer educators.

As new sex workers entered participating establishments during the intervention period, they were invited to come to the next workshop, provided with an overview of the key concepts that they had missed in prior sessions, asked to sign the collective commitment contract, and given educational materials and additional support, as needed.

\section{Facilitating environmental cues to action}

In both cities, environmental cues promoted consistent condom use among sex workers and their clients. Each sex establishment owner was encouraged to display posters and stickers promoting 100 percent condom use and to place glass bowls filled with condoms in visible locations throughout the establishment; these materials were supplied free of charge by the project. All establishments were responsible for ensuring access to high-quality condoms and maintaining a stock of at least a hundred condoms on the premises at all times. To support this process, the project sold condoms at a discount rate to establishment owners. In turn, establishment owners were encouraged to provide sex workers with at least two condoms, free of charge, as they left the establishment on a date. Many establishments sought to recoup the cost of providing these condoms free of charge to the sex worker by slightly increasing the salida or fee the client paid to the establishment to go on a date with a sex worker.

Other environmental cues included disc jockeys playing brief messages about the importance of condoms and safer sex on certain evenings. On these same nights, the disc jockey messages were reinforced by condom information booths at establishment entrances, as well as participatory theater and educational materials targeted to the male clients of female sex workers. NGO staff and 


\section{Hgrizons}

sex worker peer educators worked with the disk jockeys to develop the messages, staffed the information booths, participated in the theater presentations, and distributed the educational materials.

\section{Promoting respectful clinical services for sex workers}

Prior to the intervention, the Dominican government required female sex workers to attend monthly STI checks in government clinics. Government health inspectors were responsible for ensuring that all sex workers attended these screenings by checking that all women working in entertainment establishments had an updated STI screening card. These monthly medical checkups were generally provided free, although sometimes a small fee (\$2.50) was charged for a lost card. This system was not implemented in a standardized fashion, however, due to a lack of government resources, organization, and supervision.

The intervention sought to improve the system by first conducting a needs assessment of the public health clinics serving female sex workers and by interviewing government health inspectors. NGO staff then provided training to both public health clinicians and government health inspectors on HIV/AIDS, data collection and monitoring, human rights of sex workers, and ethical standards and procedures related to confidentiality. The project also helped government health workers successfully lobby national governmental agencies to acquire much-needed equipment, personnel, and medicines for management of STIs. Additionally, several sex worker peer educators from the project were, for the first time, given private offices in government clinics in order to provide counseling as part of STI management and voluntary HIV testing. They also helped government health inspectors remind establishment owners or managers and sex workers of the date and time of the sex workers' next STI check-up.

\section{Monitoring and encouraging compliance}

At the beginning of the project, the regional health department of Puerto Plata and the implementing NGO, CEPROSH, announced the 100 percent condom use policy at an event attended by the owners of the 34 participating sex establishments. Owners were told that they, not the sex workers, would be responsible for ensuring that the establishment complied with the 100 percent condom use policy and program activities. NGO staff and government officials in Puerto Plata met with participating sex establishment owners on a quarterly basis to encourage continued collaboration and discuss barriers to compliance.

In both Puerto Plata and Santo Domingo, government health inspectors accompanied by NGO staff visited sex establishments on a monthly basis to document and notify owners about their establishment's level of compliance with five key elements:

- The presence of posters promoting 100 percent condom use.

- Availability of at least 100 condoms.

- Condoms easily visible and accessible.

- Attendance of all establishment sex workers at monthly STI check-ups. 
- A lack of a positive STI diagnosis among sex workers working at the establishment. No individual STI results were ever shared with establishment owners. They were simply informed if their establishment was in compliance, which meant having no positive STI diagnoses among women working at the establishment that month.

The purpose of these monthly monitoring visits was to ensure continuous feedback and support to each participating sex establishment. At the end of each month, sex establishments in both cities that were not in compliance with the five elements received intensified educational efforts to boost compliance. In addition to increased educational efforts, participating sex establishments in Puerto Plata that were not in compliance with the five elements were subject to a graduated sanction system targeted to the establishment owner, including notifications, fines, and closings. In both cities, certificates were awarded on a quarterly basis to sex establishments that were in compliance with all five elements.

\section{Data Collection and Ethical Procedures}

The intervention research protocol for the study was reviewed and approved by two independent ethical review boards in the United States: the Population Council in New York and the Johns Hopkins University in Baltimore, Maryland. Additionally, DIGECITSS, the country's national AIDS control program, reviewed and approved the study with regard to both technical and ethical merit.

The research team collected evaluation data at baseline (September to December 1999) and again at the end of the 12-month intervention period (November to December 2000). The data included reported, observed, and clinical data, which were triangulated as part of data analysis to answer the research questions. A random, cross-sectional sample of approximately 200 female sex workers from participating establishments in each city completed structured sociobehavioral surveys administered by trained interviewers from local health NGOs. This sample of sex workers also underwent nonroutine STI testing before and after the intervention, specifically, urine samples for gonorrhea and chlamydia and vaginal swabs for trichomoniasis.

Participants were recruited from government health clinics where sex workers attend monthly STI checks. Every third sex worker seen by clinic physicians as part of routine care was approached and asked to participate in a private pre-survey screening. Informed consent was conducted with all women who expressed initial interest and met the study's selection criteria: 18 years of age or older and currently working in one of the 34 sex establishments. All potential participants were given detailed information about the objectives, procedures, and risks and benefits of the study. If they agreed to participate, they gave written consent to be interviewed and to participate in nonroutine STI screening. All research participants received approximately US $\$ 3$ for their time. Study participation rates were over 95 percent.

All survey interviews were anonymous and STI testing was confidential. Names were recorded with participant record numbers in a separate location from survey data. All participants were instructed to come back within one week to receive STI test results and free treatment if they tested 


\section{Hgrizons}

positive. NGO peer educators confidentially contacted participants who tested positive but did not come back within one week, and provided them with treatment for their STI.

Participant observation was also conducted pre- and post-intervention among a random sample of 64 sex workers recruited from participating sex establishments in each city. The project team selected male NGO staff members to pose as male clients and trained them in participant observation methodology and research ethics. After selecting a woman based on established criteria, NGO staff followed a strict research protocol: they talked with the woman for approximately 30 minutes and then asked if she would be willing to have sex without a condom, using up to four reasons why a condom should not be used (see below for the specific four reasons). After the sex worker gave her final response, he excused himself from the interaction, paid the bill for his table, and compensated the sex worker with a tip of approximately US\$6 for her time. All interactions were anonymous and took place within the confines of the sex establishment. After leaving the establishment, NGO staff documented the interaction in a private setting. Results were not shared with anyone outside the research team. The local sex worker organization MODEMU was consulted on and approved the observation methodology as part of evaluation efforts.

In addition to individual-level data collected pre- and post-intervention, data were also collected on a monthly basis at each of the participating sex establishments to document compliance with the five key intervention elements, as described above.

\section{Measures}

Condom use behavior was assessed in surveys by participant self-reports of the percent of sex acts in which they used condoms in the last month with new clients, regular paying and non-paying partners, and all partners. New clients were defined as people they had sex with only once or twice in exchange for money. Regular partners were defined as people they had sex with at least three times or had a relationship of trust with, whether they directly paid for sex or not. Hence, the regular partner category included both paying and non-paying partners. For new clients and regular partners, a five-point Likert scale was used to measure the frequency of condom use: always, almost always, sometimes, almost never, and never. For all partners, participants were asked how many sexual partners they had sex with in the last month and with how many of them they always used condoms.

Rejection of unsafe sex was measured by participant observation of female sex workers by NGO staff posing as male clients. Formative research revealed common excuses men give for not wanting to use condoms with sex workers. The research team chose four reasons to be used by the mystery clients: he doesn't condoms, he is a "serious guy who is married and has kids," he will offer 50 percent more money than her asking rate, and he will offer 100 percent more money than her asking rate. The NGO worker posing as a male client recorded if the sex worker accepted any of these reasons or if she verbally rejected unsafe sex throughout the encounter. 
Sexually transmitted infections were documented by calculating the prevalence of each of the three curable STIs assessed by the study among participating female sex workers: gonorrhea, chlamydia, and trichomoniasis. We then constructed a dichotomized measure of whether participants had any of these three STIs. Chlamydia and gonorrhea were detected using Ligase chain reaction (LCR) DNA tests, while the presence of trichomoniasis was established using culture-based tests. Treatment was provided to all women testing positive for any STI at both pre- and post-test.

Exposure to the intervention: Within the pre-post survey instrument conducted with participating sex workers in each city, reported exposure to the intervention was measured using an 13-item scale (Cronbach's alpha $=.80$ ), including female sex workers' participation in, exposure to, and/or perceptions of the key intervention components in the last month, including the following items:

- Collective commitment: participated in solidarity-building workshops and receipt of educational materials, signed a collective commitment contract, experienced support or encouragement from owners/managers, employees, or sex workers about condom use.

- Environmental cues: viewed posters or condoms in the establishment and had stable access to condoms in the establishment.

- Policy: heard the establishment owner communicate a clear 100 percent condom use policy and/or knew of owner-led meeting to reinforce this policy or norm.

- Monitoring: attended monthly STI check-up and/or saw a government health inspector come to the establishment to check for updated check-up.

The reported exposure scale was then dichotomized at the median point of the scale's distribution, into high exposure (positive response 11 items or more) versus low exposure (positive response to 10 items or less).

Compliance with the intervention: An observed measure of the level of compliance with the intervention was calculated using data from the monthly environmental checks conducted at each establishment during the 12-month intervention period. Each establishment received a score of 0-5 for each month depending on how many of the five key intervention elements it had complied with in the last month, including: (1) the presence of 100 percent condom posters in the establishment, (2) visible condoms in glass bowls or other receptacles within the establishment, (3) stocks of at least 100 condoms on the establishment premises, (4) attendance of all sex workers at monthly STI checks, and (5) lack of a positive STI diagnosis among sex workers working at the establishment. The average or mean level of compliance with all five of these elements over the one-year intervention period was then calculated per establishment and applied to individuals working within each sex establishment for the purpose of regression analyses.

Sociodemographic information, such as age in years, number of years of school completed, civil status (married or in union versus single or divorced), number of dates with clients in the last week, total number of all sexual partners in last month, and the average fee charged per client date, was also collected within the context of pre- and post-test surveys with participating sex workers. 


\section{Hgrizons}

\section{Data Management and Analysis}

Data analysis was conducted with two software packages: SPSS 11.0 ( ) for Windows (univariate and bivariate) and STATA Intercooled Version 7.0 () (multivariate). Univariate analyses included frequencies and distributions of all study variables and were conducted with both pre- and postintervention data. Continuous variables were examined for normalcy and categorized based on distributions at the median. All condom use variables were then dichotomized into consistent (always or with all partners) vs. inconsistent condom use (less than always or less than all partners). Bivariate analyses included chi-square tests of association and independent sample ttests. These tests were conducted to assess whether statistically significant differences in HIVrelated risk outcomes, exposure to and compliance with the intervention, and sociodemographic characteristics existed in comparing the pre- to post-intervention samples.

Bivariate and multivariate logistic regression analysis was conducted on data from sex workers reporting one or more partners in the last month, using post-intervention data to determine the unadjusted and adjusted odds of consistent condom use with all partners in the last month per level of exposure to and compliance with the intervention (controlling for other sociodemographic factors). Bivariate and multivariate regression analyses were conducted, with both including and excluding cases with missing information. No statistically significant differences were detected in the results of these analyses; hence, 42 post-intervention cases containing missing data were excluded from final regression analysis.

Standard errors from regression analyses were adjusted for the potential "cluster effect" surrounding reported condom use among women from the same sex establishment. These adjustments were made using the Huber-White robust correlation coefficient. All variables included in the final multivariate regression model were tested for collinearity prior to their inclusion in the model. 


\section{Results}

\section{Characteristics of the Sample}

The median age of female sex workers participating in the baseline survey was approximately 25 years (Table 1$)$. The percent of women over 25 did not vary significantly across cities $(\mathrm{p}=.167)$. Among women from both cities, the median number of years of schooling completed was 7.0 years. The percent of women who completed more the primary school ( $>8$ years) was not significantly different across cities $(\mathrm{p}=.378)$. While more than 70 percent of participating women from both cities reported their official civil status as single, over 65 percent from each city reported currently having a regular partner. Neither civil status $(\mathrm{p}=.901)$, nor having a regular partner $(\mathrm{p}=$ .328) varied significantly across the two cities.

The median number of dates with clients in the last week among sex workers from Santo Domingo was 1.0 (0-30), compared to $2.0(0-32)$ among sex workers from Puerto Plata. The median number of total sex partners in the last month was $2.0(0-40)$ among women from Santo Domingo and 3.0 (0-50) among women from Puerto Plata. The percent of women reporting three or more sexual partners in the last month varied significantly across cities (p.000), whereas 24.9 percent of women from Santo Domingo reported having three or more sexual partners in the last month, compared to 49.7 percent in Puerto Plata. The median, average amount of money charged per client date was US\$18 among participants from both cities. However, the percent of women charging more than $\$ 18$ per date varied significantly per city $(\mathrm{p}=.002)$, with a higher percent of sex workers from Santo Domingo, 42.9 percent, charging \$19 or more per date than women from Puerto Plata, 28.5 percent.

Some sociodemographic characteristics differed significantly from baseline to follow-up $(\mathrm{p}<.05)$. In Santo Domingo, there were more married women in the sample at follow-up than at baseline. In Puerto Plata, there were more women with lower levels of education, with more than two dates in the last week, and currently with a regular partner, at follow-up versus baseline. In both cities, there were more participants with more than three sexual partners in the last month at follow-up compared to baseline. 
Table 1 Sociodemographic and behavioral characteristics at baseline

\begin{tabular}{|c|c|c|c|}
\hline \multirow[t]{2}{*}{ Variables } & \multicolumn{2}{|c|}{ Median/range and frequencies } & \multirow[t]{2}{*}{ p-value } \\
\hline & $\begin{array}{l}\text { Santo Domingo } \\
(\mathrm{n}=210)\end{array}$ & $\begin{array}{l}\text { Puerto Plata } \\
(\mathrm{n}=200)\end{array}$ & \\
\hline Age in years & $24.0(18-40)$ & $25.0(18-51)$ & .167 \\
\hline $18-25$ & 60.8 & 54.0 & \\
\hline $26+$ & 39.2 & 46.0 & \\
\hline Education in years & $7.0(0-13)$ & $7.0(0-12)$ & .378 \\
\hline $0-8$ & 69.0 & 73.0 & \\
\hline $9+$ & 31.0 & 27.0 & \\
\hline Civil status & & & .901 \\
\hline Single & 72.1 & 71.5 & \\
\hline Married & 27.9 & 28.5 & \\
\hline Currently has a regular partner & & & 328 \\
\hline Yes & 68.6 & 64.0 & \\
\hline No & 31.4 & 36.0 & \\
\hline Number of client dates in last week & $1(0-30)$ & $2(0-32)$ & .020 \\
\hline$<2$ & 56.5 & 44.7 & \\
\hline $2+$ & 43.5 & 55.3 & \\
\hline $\begin{array}{l}\text { Total number of sexual partners in the } \\
\text { last month }\end{array}$ & $1(0-40)$ & $2(0-50)$ & .000 \\
\hline$<3$ & 75.1 & 50.3 & \\
\hline $3+$ & 24.9 & 49.7 & \\
\hline Average fee charged per client date & $\$ 18(12-90)$ & $\$ 18(12-60)$ & .002 \\
\hline$\$ 0-18$ & 57.1 & 71.5 & \\
\hline$\$ 19+$ & 42.9 & 28.5 & \\
\hline
\end{tabular}

\section{Pre- to Post-intervention Changes in HI V-related Risk}

\section{Consistent condom use}

Reported consistent condom use (CCU) with new clients in the last month at baseline was 75.3 percent in Santo Domingo, compared to 96.5 percent in Puerto Plata (Table 2). The rate of consistent condom use with new clients increased among participants at post-intervention compared to pre- intervention in both cities, to 93.8 percent in Santo Domingo and to 98.6 percent in Puerto Plata. However, given the already high rates of condom use with new clients in Puerto Plata at baseline, this change was statistically significant only in Santo Domingo $(\mathrm{p}=.000)$.

In the case of regular paying and non-paying partners, the base rates of CCU were similar across the two cities: 14.6 percent in Santo Domingo vs. 13.0 percent in Puerto Plata. However, the rate of 
consistent condom use with regular partners in the last month increased significantly at post-test in Puerto Plata only $(\mathrm{p}=.001)$, reaching 28.8 percent.

Table 2 Consistent condom use per partner type in the last month, pre- to postintervention

\begin{tabular}{|c|c|c|c|c|c|c|c|c|c|c|c|c|}
\hline \multirow{3}{*}{$\begin{array}{l}\text { Partner } \\
\text { type }\end{array}$} & \multicolumn{6}{|c|}{ Santo Domingo } & \multicolumn{6}{|c|}{ Puero Plata } \\
\hline & \multicolumn{2}{|c|}{ Pre } & \multicolumn{2}{|c|}{ Post } & \multicolumn{2}{|c|}{$p$-value } & \multicolumn{2}{|c|}{ Pre } & \multicolumn{2}{|c|}{ Post } & \multicolumn{2}{|c|}{$p$-value } \\
\hline & $\%$ & $\mathbf{n}$ & $\%$ & $\mathbf{n}$ & & $\mathbf{n}$ & $\%$ & $\mathbf{n}$ & $\%$ & $\mathbf{n}$ & & $\mathbf{n}$ \\
\hline $\begin{array}{l}\text { New } \\
\text { clients }\end{array}$ & 75.3 & 93 & 93.8 & 113 & .000 & 206 & 96.5 & 115 & 98.6 & 141 & .279 & 256 \\
\hline $\begin{array}{l}\text { Regular } \\
\text { partners }\end{array}$ & 14.6 & 144 & 17.6 & 165 & .476 & 309 & 13.0 & 131 & 28.8 & 153 & .001 & 284 \\
\hline
\end{tabular}

The "n"s in Table 2 represent the number of participants that reported having such partners in the last month, who were then asked about and responded to whether they used condoms consistently with those partners.

\section{Verbal rejection of unsafe sex}

Sex workers' verbal ability to reject unsafe commercial sex increased from pre- to postintervention in both cities. However, statistically significant increases were documented in Puerto Plata only (Table 3). These increases were found at each of the four levels of social interaction assessed by the study. The total percent of participating sex workers able to verbally reject unsafe sex after all four scenarios were presented to them increased almost 30 percentage points, from 50.0 to 79.4 percent $(\mathrm{p}=.000)$, from pre- to post-intervention in Puerto Plata. In Santo Domingo, the verbal ability of sex workers to reject unsafe sex increased from 64.2 to 72.3 percent $(p=316)$.

Table 3 Verbal rejection of unsafe sex, pre- to post-intervention

\begin{tabular}{lccc|ccc}
\hline $\begin{array}{l}\text { Cumulative \% rejecting } \\
\text { unsafe sex per level }\end{array}$ & \multicolumn{3}{c|}{ Santo Domingo } & \multicolumn{3}{c}{ Puerto Plata } \\
& $\begin{array}{l}\text { Pre- } \\
\mathbf{n}=\mathbf{6 7}\end{array}$ & $\begin{array}{c}\text { Post- } \\
\mathbf{n}=\mathbf{6 5}\end{array}$ & $\begin{array}{c}\mathbf{p} \text {-value } \\
\mathbf{n}=\mathbf{1 3 2}\end{array}$ & $\begin{array}{c}\text { Pre- } \\
\mathbf{n}=\mathbf{6 4}\end{array}$ & $\begin{array}{c}\text { Post- } \\
\mathbf{n}=\mathbf{6 8}\end{array}$ & $\begin{array}{c}\mathbf{p} \text {-value } \\
\mathbf{n}=\mathbf{1 3 2}\end{array}$ \\
\hline $\begin{array}{l}\text { Stated he didn't like } \\
\text { condoms }\end{array}$ & 76.1 & 78.5 & .748 & 79.7 & 94.1 & .013 \\
Stated he was "serious guy" & 71.6 & 76.9 & .488 & 64.1 & 91.2 & .000 \\
Offered 50\% more money & 67.2 & 73.8 & .400 & 54.7 & 83.8 & .000 \\
Offered 100\% more money & 64.2 & 72.3 & .316 & 50.0 & 79.4 & .000
\end{tabular}




\section{Sexually transmitted infections}

Significant decreases were detected in the prevalence of STIs (gonorrhea, trichomoniasis, and/or chlaymdia) measured by the study in both cities, with a slightly stronger decline documented in Puerto Plata (28.8 to 16.3 percent, $\mathrm{p}=.003$ ), compared to Santo Domingo (25.5 to 15.9 percent, $\mathrm{p}=.014)$. Reductions in distinct STIs appear to be driving the overall reductions in prevalence across the two cities. In the case of Santo Domingo, the prevalence of chlamydia decreased significantly from 16.4 to 9.3 percent $(\mathrm{p}=.029)$, while in Puerto Plata the prevalence of trichomoniasis decreased significantly from pre- to post-test, from 9.6 to 3.9 percent $(p=.024)$.

Table 4 Sexually transmitted infections, pre- to post-intervention

\begin{tabular}{lccc|ccc}
\hline Type of STI & \multicolumn{3}{c|}{ Santo Domingo } & \multicolumn{3}{c}{ Puerto Plata } \\
& $\begin{array}{l}\text { Pre- } \\
\mathbf{n = 2 2 0}\end{array}$ & $\begin{array}{c}\text { Post- } \\
\mathbf{n = 2 1 4}\end{array}$ & $\begin{array}{c}\mathbf{p} \text {-value } \\
\mathbf{n}=\mathbf{4 3 4}\end{array}$ & $\begin{array}{c}\text { Pre- } \\
\mathbf{n = 1 9 8}\end{array}$ & $\begin{array}{c}\text { Post- } \\
\mathbf{n}=\mathbf{2 0 4}\end{array}$ & $\begin{array}{l}\text { p-value } \\
\mathbf{n}=\mathbf{4 0 2}\end{array}$ \\
\hline Gonorrhea & 2.3 & 1.9 & .768 & 6.6 & 3.9 & .234 \\
Trichomoniasis & 9.1 & 6.1 & .236 & 9.6 & 3.9 & .024 \\
Chlamydia & 16.4 & 9.3 & .029 & 14.6 & 9.8 & .138 \\
One or more of three & 25.5 & 15.9 & .014 & 28.8 & 16.3 & .003 \\
STls & & & & & &
\end{tabular}

\section{Exposure to and compliance with the intervention}

In both cities, reported exposure to the intervention at pre- vs. post-intervention data collection rounds increased significantly, with average scores on a 13-point exposure scale increasing from 6.6 to 10.21 in Santo Domingo $(\mathrm{p}=.000)$ and from 9.5 to 11.72 in Puerto Plata $(\mathrm{p}=.000)$.

However, compliance with the intervention revealed a very different story across the two cities.

Figure 1 shows the average level of compliance with the five key environmental elements observed on a monthly basis over the course of the 12-month intervention period: (1) visible 100 percent condom posters, (2) visible glass bowl filled with condoms, (3) stock of more than 100 condoms on the premises, (4) all women attending STI checks, and (5) no women testing positive for STIs. Based on these data, the average level of observed compliance increased more steadily and intensely in Puerto Plata than in Santo Domingo. The average level of compliance with these five intervention elements in participating establishments in Santo Domingo was 3.3 at Month 1, and ended at almost the same point, 3.0, at Month 12 of the intervention. In establishments in Puerto Plata, the average level of compliance with the five intervention elements started at 2.6 at Month 1 and rose significantly to 4.7 by Month 12 of the intervention $(\mathrm{p}=.000)$. 
Figure 1 Average level of observed compliance with environmental intervention elements among participating sex establishments in Santo Domingo (SD) and Puerto Plata (PP) $(n=68)$

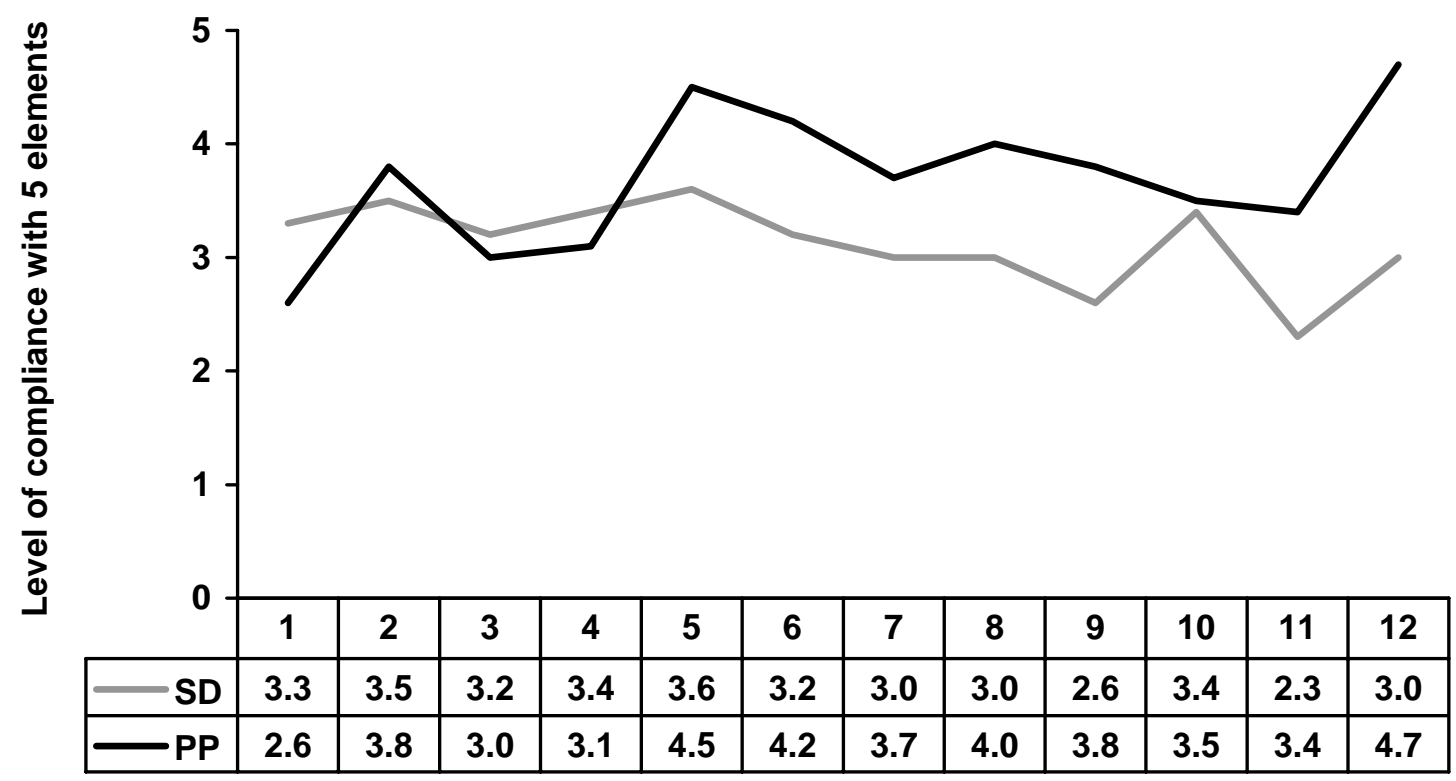

Month of intervention

Note: The five elements include: (1) the presence of 100 percent condom posters in the establishment, (2) visible condoms in glass bowls or other receptacles within the establishment, (3) stocks of at least 100 condoms on the establishment premises, (4) attendance of all sex workers at monthly STI checks, and (5) lack of a positive STI diagnosis among sex workers working at the establishment.

\section{Assessing the effects of exposure to and compliance with the intervention on consistent condom use}

Table 5 shows the unadjusted and adjusted odds of consistent condom use with all partners in the last month based on the level of exposure to and observed compliance with the intervention as well as other sociodemographic factors that may be associated with CCU among female sex workers across both cities. Bivariate analysis shows that both reported exposure to, and observed compliance with, the intervention are significantly associated with increased condom use, whereas the odds of CCU were 1.99 greater among participating sex workers with higher levels of reported exposure to the intervention, and 3.76 times greater among sex workers from participating sex establishments with the highest level of observed compliance to key intervention components.

Reporting more than two dates with clients in the last week was also significantly associated with increased CCU in bivariate analysis. Variables significantly associated with inconsistent condom 


\section{Hgrizons}

use with all partners in the last month include being married or in union and having a current regular partner. Additionally, the city in which sex workers were based was also a significant predictor of consistent condom use. Women from Puerto Plata, for example, were 2.29 times as likely to use condoms consistently with all partners in the last month as women from Santo Domingo in bivariate analyses.

In multivariate analysis, exposure and compliance remain significantly associated with consistent condom use. Participants with high levels of reported exposure to the intervention were 1.84 times more likely to use condoms consistently, compared to women with low levels of reported exposure. Participants working in sex establishments with the highest levels of observed compliance with the intervention were 2.33 times more likely to use condoms consistently, compared to women with low levels of reported exposure. Being married and having a current regular partner also remained significantly associated with inconsistent condom use. City remained a significant predictor of $\mathrm{CCU}$ when controlling for all other variables, with the exception of observed compliance to the five structural intervention elements. However, when observed compliance was controlled for in the model, the significant association found between city and CCU was no longer present. 
Table 5 Effects of exposure to and compliance with the intervention on consistent condom use with all partners in the last month, post-intervention $(n=333)$

\begin{tabular}{|c|c|c|c|c|c|c|}
\hline \multirow[t]{2}{*}{ Variables } & \multicolumn{3}{|c|}{ Unadjusted odds ratio } & \multicolumn{3}{|c|}{ Adjusted odds ratio } \\
\hline & OR & $95 \% \mathrm{Cl}$ & p-value & OR & $95 \% \mathrm{Cl}$ & $p$-value \\
\hline \multicolumn{7}{|l|}{$\begin{array}{l}\text { Reported exposure } \\
\text { to the intervention } \\
\text { Low }\end{array}$} \\
\hline \multicolumn{7}{|l|}{$\begin{array}{l}\text { Average level of } \\
\text { observed } \\
\text { compliance with the } \\
\text { intervention }\end{array}$} \\
\hline $0.0-3.0$ & 2.28 & $1.22-4.30$ & .010 & 1.60 & $.79-3.25$ & .195 \\
\hline $3.01-3.50$ & 3.71 & $1.98-6.94$ & .000 & 2.43 & $.97-6.15$ & .059 \\
\hline $\begin{array}{l}3.51-4.00 \\
>4.00\end{array}$ & 3.76 & $1.95-7.26$ & .000 & 2.33 & $1.01-5.39$ & .047 \\
\hline $\begin{array}{l}\text { City } \\
\text { Santo Domingo }\end{array}$ & & & & & & \\
\hline $\begin{array}{l}\text { Puerto Plata } \\
\text { Age in years } \\
18-25\end{array}$ & 2.29 & $1.48-3.56$ & .000 & 1.45 & $.68-3.06$ & .332 \\
\hline $\begin{array}{l}26+ \\
\text { Education in years } \\
0-8\end{array}$ & .97 & $.62-1.50$ & .876 & .98 & $.60-1.60$ & .936 \\
\hline $\begin{array}{l}9+ \\
\text { Civil status }\end{array}$ & .91 & $.56-1.48$ & .696 & .89 & $.45-1.76$ & .743 \\
\hline $\begin{array}{l}\text { Single/divorced } \\
\text { Married/in union }\end{array}$ & .24 & $.15-.39$ & .000 & .40 & $.26-.61$ & .000 \\
\hline $\begin{array}{l}\text { Currently has } \\
\text { regular partner } \\
\text { No }\end{array}$ & & & & & & \\
\hline $\begin{array}{l}\text { Yes } \\
\text { Number of client } \\
\text { dates last week } \\
<2\end{array}$ & .08 & $.04-.18$ & .000 & .10 & $.04-.25$ & .000 \\
\hline $\begin{array}{l}2+ \\
\text { Total number of } \\
\text { partners last montl } \\
\quad<3\end{array}$ & 1.68 & $1.10-2.60$ & .020 & 1.22 & $.63-2.35$ & .560 \\
\hline $\begin{array}{l}\text { 3+ } \\
\text { Average fee } \\
\text { charged per client } \\
\text { date }\end{array}$ & 1.07 & $.69-1.65$ & .761 & .68 & $.32-1.45$ & .321 \\
\hline $\begin{array}{l}\text { US } \$ 0-18 \\
\text { US } \$ 19+\end{array}$ & 1.53 & $.98-2.40$ & .064 & 1.24 & $.72-2.13$ & .433 \\
\hline
\end{tabular}




\section{Hgrizons}

\section{Other Outcomes of the I ntervention}

Several additional indicators were assessed by the study to examine the effects of the intervention on participant's perception of their environment and to ensure that the intervention did not have any unintended negative consequences for participating women.

Reported abuse or mistreatment in the last three months by sex establishment owners, male employees, and male clients towards participating sex workers was assessed. In the case of Puerto Plata, no significant changes in abuse or mistreatment by members of any of these three groups were found pre- to post-intervention. In Santo Domingo, one significant positive change was documented: the reported level of abuse or mistreatment in the last three months on the part of male clients toward participating sex workers declined from 30.2 to 18.0 percent, pre- to postintervention $(\mathrm{p}=.015)$. Participating sex workers were also asked if sex establishment owners had imposed any type of fine upon them in the last three months. Sex workers are often fined by owners for being late or for other issues not necessarily related to the intervention. The percent of sex workers who reported that they'd received a fine for any reason in the last three months did not change significantly in either city pre- to post-intervention.

The last workshop with each of the three main intended audiences of the intervention (sex workers, sex establishment owners/managers, and other male establishment employees) provided an opportunity to discuss participants' experiences with the intervention. Additionally, open-ended questions were asked of participating sex workers at post-test about how the intervention may have positively or negatively affected them and their relationships with establishment owners or employees, clients, and/or other sexual partners. All three groups reported on positive and/or useful elements of the intervention. For example, many sex workers reported that the intervention helped them value and protect themselves and their families. Establishment employees reported that for the first time they were taken into consideration and given the opportunity to positively contribute to society. Additionally, all three groups reported an increased sense of awareness of the challenges of preventing HIV/STIs and documented the importance of working on this issue collectively rather than in isolation.

The final workshop also provided an opportunity to discuss the sex establishment owners' attitudes and reactions to the regional, governmental 100 percent condom policy model and graduated sanction system in Puerto Plata. During the course of the intervention in Puerto Plata, 113 notifications, 18 fines, and one temporary closing were levied on participating sex establishments from that city due to noncompliance with the five key intervention elements assessed on a monthly basis. Sex establishment owners from Puerto Plata generally stated that complying with all five intervention elements on a monthly basis was challenging. However, most agreed that they much preferred the transparent policy and regulation system establishment implemented through the 100 percent condom use initiative, which had been developed with their input and the input of other stakeholders, compared to the prior government monitoring and enforcement system, which was plagued by reports of corruption and manipulation. 


\section{Cost-effectiveness Analysis}

\section{Methods}

The research team modeled the incremental cost-effectiveness of implementation of an environmental-structural intervention in Santo Domingo and Puerto Plata, comparing the intervention conducted in each city to receiving no intervention. Model outcomes include program costs, the number of HIV infections averted, the cost per HIV infection averted, and the cost per Disability Adjusted Life Year (DALY) saved from the intervention. Results were modeled based on the impact per 10,000 female sex workers reached by the intervention in each study city.

The researchers examined what the intervention would cost from the perspective of the implementing nongovernmental organizations. While the government participated in the intervention by providing STI diagnosis and treatment and by enforcing sanctions in Puerto Plata, the costs were negligible, since STI services were already provided and the government already inspected sex establishments. The main enhancement for the government was in enforcing regulations and monitoring environmental compliance with the intervention, which was done at the same time as other routine inspections they conducted. Government inspectors accompanied by NGO workers collected the results of monthly STI screening of sex workers at public clinics and sanctioned the owners of establishments where female sex workers testing positive for STIs were employed. Thus, for this analysis we asked the question, "What is the cost-effectiveness of implementing each intervention model of the environmental-structural intervention in geographic settings that have a system of monthly STI screening among establishment-based female sex workers?"

Estimation of DALYs saved. To estimate the number of DALYs saved from the intervention, we calculated the number of DALYs lost from an HIV infection due to both disability associated with HIV infection and premature death from AIDS. We estimated life expectancy at the average age of HIV infection based on a review of available demographic data (United Nations Population Division 2001). This life expectancy estimate is based on average life expectancy independent of HIV infection for the base-case analysis. Disability weights for HIV infection and AIDS were estimated to be 0.123 and 0.505, respectively (Murray and Lopez 1996). Disease progression parameters were adapted from published literature (Hendricks et al. 1996), which estimates an eight-year estimate for moving from HIV-1 infection to AIDS and a one-year progression from AIDS to death, as recommended by UNAIDS for developing countries.

We adjusted the number of DALYs saved by age and discounted the number of DALYs saved to reflect age preferences by using standard analytic techniques (Murray et al. 1996). Future costs and benefits were discounted at a rate of 3 percent, with sensitivity analysis for 0 percent and 6 percent. The total number of DALYs saved from the intervention was calculated by multiplying the annual number of infections averted by the number of DALYs from disability and early mortality saved per HIV infection averted. 


\section{Hgrizons}

Measurement of costs. Intervention costs were calculated by estimating the per client quantity of goods and services utilized in delivery of the intervention. These were derived from cost worksheets developed for the project, project records, budgets, and interviews with project staff and managers. All research costs were removed, and the final cost estimates utilized were adjusted by examination of actual costs of service provision when the research was terminated and each site transferred to pure service provision. The per client cost of the intervention reflects the cost to the implementing NGO.

Government participation incurred negligible costs because there were already STI services in place and government inspectors already visit brothels. The results of the analysis are presented per 10,000 clients under the assumption of full project implementation in a given setting, and also to allow for comparison to other cost-effectiveness analyses. All costs were converted to 2001 U.S. dollars for presentation.

Study model. Estimates of the number of HIV infections averted were derived from the following widely used probability-based formula (Weinstein et al. 1989):

[Equation 1]: Probability of HIV Infection $(P)=1-\left\{p[1-r(1-f e)]^{n}+(1-p)\right\}^{m}$

Where $\mathrm{p}$ is the average HIV prevalence among sexual partners of the target population, $r$ is the risk of HIV transmission per act of unprotected sex (also known as "infectivity"), $f$ is the fraction of sex acts when a condom is used, e is the effectiveness of condoms, $n$ is the average number of sex acts per partner, and $\mathrm{m}$ is the average number of sex partners. Model estimates were calculated separately by city and also by sexual partner types (regular paying, regular non-paying, and new paying clients). Given that female sex workers targeted in the intervention are at risk from two types of partners (regular and new), each incurring a different estimated probability of infecting the woman, we combined the annualized risk from both partner types with the following formula:

[Equation 2]: Combined Probability of HIV Infection $=\left((\operatorname{Pr}+\operatorname{Pn})_{-}(\operatorname{Pr} * \operatorname{Pn})\right)$

Where $\mathrm{Pr}$ is the annual probability of HIV infection from regular partners, and $\mathrm{Pb}$ is the annual probability of HIV infection from new paying clients. Pr and Pn are first calculated separately from equation 1, then combined in equation 2. Thus, the model estimates HIV transmission from three sources that could be affected by the intervention: (a) HIV-negative female sex workers targeted for the intervention becoming infected from regular and new partners, (b) HIV-negative regular partners becoming infected from female sex workers targeted for the intervention, and (c) HIVnegative new partners becoming infected from female sex workers targeted for the intervention.

Sensitivity analysis. Sensitivity analysis was conducted using a Monte Carlo model to examine how variations in epidemiologic, economic, and behavioral model parameters affect the costeffectiveness of the intervention. The stochastic model was developed from the base-case model using triangular probability distribution functions with high / average/ low values. For many epidemiologic and economic values, these were estimated from published reports. Behavioral and STI data were taken from study data and point estimates and the upper and lower bound of the 95 
percent confidence interval was used for sensitivity analysis. Iterations of the model were conducted until changes in the sampled variable values and associated model outcomes changed by less than 1.5 percent in both the mean and standard deviation.

The resulting output is a set of varying values of model inputs (across all parameters simultaneously), with associated outcomes for each iteration of the model. Sets of parameters were differentially fixed or allowed to vary in various model simulations for one-, two-, and three-way sensitivity analyses. The stochastic model was also used for multivariate sensitivity analysis.

\section{Model parameters}

Epidemiologic. Base-case values for epidemiologic model parameters and associated ranges for each parameter used in sensitivity analysis are shown in Table 6. HIV seroprevalence among female sex workers was estimated from recent surveillance studies conducted in each city. The researchers assumed that the HIV prevalence for male sexual partners of sex workers was equal in the case of the partners of HIV-positive female sex workers and 25 percent less in the case of the partners of uninfected female sex workers. The 95 percent confidence interval used in sensitivity analysis. HIV-1 infectivity values come from published data and were adjusted for STI coinfection. Male-to-female HIV-1 infectivity was assumed to be 0.002 per sex act between an infected male and an uninfected female; for female-to-male infectivity, the assumption is 0.001 per sex act for infected female to uninfected male 0.001 (Rehle et al. 1998). If a genital ulcerative disease (GUD) is present in either partner, the rate of transmission was assumed to be 0.06; with non-GUDs (chlamydia, trichomoniasis, and gonorrhea) present, the rate is estimated at 0.02 for male to female, and 0.01 female to male (Rehle et al. 1998).

Prevalence of non-GUDs was observed in the study, and we used the rates from baseline and follow up in the model to estimate weighted averages of HIV infectivity. GUD rates were estimated to be 5 percent for female sex workers. GUD was not assessed among female sex workers in this study, thus we opted to conservatively set the value as a constant from baseline to follow up. Pre- and post-intervention values for the adjusted HIV infectivity rate are shown for males and females by city. 
Table 6 Base-case values for epidemiologic parameters (1-year time frame)

\begin{tabular}{|c|c|c|c|c|}
\hline Parameter & Site & $\begin{array}{l}\text { Base- } \\
\text { Case } \\
\text { Estimate }\end{array}$ & Range & Data Source \\
\hline HIV prevalence of & Puerto Plata & & & \multirow[b]{2}{*}{$\begin{array}{l}\text { Sentinel } \\
\text { surveillance } \\
(95 \% \mathrm{Cl})\end{array}$} \\
\hline $\begin{array}{l}\text { female sex workers } \\
\text { HIV prevalence of male } \\
\text { sex partners of HIV- } \\
\text { infected female sex } \\
\text { workers }\end{array}$ & $\begin{array}{l}\text { Santo Domingo } \\
\text { Puerto Plata } \\
\text { Santo Domingo }\end{array}$ & $5.68 \%$ & (3.38-7.99\%) & \\
\hline $\begin{array}{l}\text { HIV prevalence of male } \\
\text { sex partners of HIV- } \\
\text { uninfected female sex } \\
\text { workers }\end{array}$ & Santo Domingo & $4.3 \%$ & (2.54-5.99\%) & \multirow[t]{2}{*}{$\begin{array}{l}\text { Estimated } 25 \% \\
\text { less than } \\
\text { prevalence among } \\
\text { female sex } \\
\text { workers }\end{array}$} \\
\hline $\begin{array}{l}\text { Pre-intervention } \\
\text { prevalence of non-GUD } \\
\text { STI }\end{array}$ & $\begin{array}{l}\text { Puerto Plata } \\
\text { Santo Domingo }\end{array}$ & $\begin{array}{l}28.8 \% \\
25.5 \%\end{array}$ & $\begin{array}{l}22.4-35.2 \% \\
19.7-31.3 \%\end{array}$ & \\
\hline $\begin{array}{l}\text { Post-intervention } \\
\text { prevalence of non-GUD } \\
\text { STI }\end{array}$ & $\begin{array}{l}\text { Puerto Plata } \\
\text { Santo Domingo }\end{array}$ & $\begin{array}{l}16.3 \% \\
15.9 \%\end{array}$ & $\begin{array}{l}11.1-21.4 \% \\
11.0-20.8 \%\end{array}$ & $\begin{array}{l}\text { Observed } \\
\text { (Range 95\% Cl) }\end{array}$ \\
\hline $\begin{array}{l}\text { Pre/post estimate of } \\
\text { GUD STI prevalence }\end{array}$ & $\begin{array}{c}\text { Puerto Plata } \\
\text { Santo Domingo }\end{array}$ & $\begin{array}{l}5 \% \\
5 \%\end{array}$ & $\begin{array}{l}(2 \%-10 \%) \\
(2 \%-10 \%)\end{array}$ & \multirow[t]{2}{*}{$\begin{array}{l}\text { Estimated from } \\
\text { surveillance }\end{array}$} \\
\hline $\begin{array}{l}\text { Pre-intervention } \\
\text { probability of HIV } \\
\text { infection per sex act for } \\
\text { HIV-uninfected females }\end{array}$ & Santo Domingo & 0.00559 & $0.00278-0.00834$ & \\
\hline Post-intervention & Puerto Plata & 0.00496 & $0.00249-0.00744$ & \multirow{6}{*}{$\begin{array}{l}\text { Base rate of } 0.001 \\
\text { adjusted for STI } \\
\text { co-infection } \\
\text { (range varies with } \\
\text { STD range } \\
\text { adjustment) }\end{array}$} \\
\hline $\begin{array}{l}\text { infection per sex act for } \\
\text { HIV-uninfected females }\end{array}$ & Santo Domingo & 0.00482 & $0.00241-0.00723$ & \\
\hline $\begin{array}{l}\text { Pre-intervention } \\
\text { probability of HIV }\end{array}$ & Puerto Plata & 0.00642 & $0.00321-0.00963$ & \\
\hline $\begin{array}{l}\text { infection per sex act for } \\
\text { HIV-uninfected males }\end{array}$ & Santo Domingo & 0.00633 & $0.00317-0.00950$ & \\
\hline $\begin{array}{l}\text { Post-intervention } \\
\text { probability of HIV }\end{array}$ & Puerto Plata & 0.00579 & $0.00290-0.00869$ & \\
\hline $\begin{array}{l}\text { infection per sex act for } \\
\text { HIV-uninfected males }\end{array}$ & Santo Domingo & 0.00574 & $0.00287-0.00861$ & \\
\hline
\end{tabular}


Behavioral. Sexual behavior parameters were estimated from specific questions asked to study participants regarding number and type of sexual partners, number and type of sexual acts, and the number of sexual acts in which a condom was used. All behavioral values were annualized.

Sensitivity analysis was conducted on these sexual behavior parameters using the upper and lower bounds of the 95 percent confidence intervals. Some parameters for male partners were estimated, as indicated in Table 7. Note that we opted to use self-reported behaviors from sex workers, rather than observations gleaned from participant observations. This is a more conservative approach (biased toward less cost-effective outcomes), provides a larger sample size for analysis, and allows us to generate estimates by partner types. 
Table 7 Base-case values for behavioral parameters (1-year time frame)

\begin{tabular}{|c|c|c|c|c|}
\hline Parameter & Site & $\begin{array}{l}\text { Base-case } \\
\text { estimate }\end{array}$ & $95 \% \mathrm{Cl}$ & Data source \\
\hline \multicolumn{5}{|l|}{$\begin{array}{l}\text { For regular male partners } \\
\text { (paying and non-paying) }\end{array}$} \\
\hline \multirow{2}{*}{$\begin{array}{l}\text { Pre-intervention percent } \\
\text { condom use per sex act }\end{array}$} & Puerto Plata & $13.0 \%$ & $7.2-18.1 \%$ & Observed $(95 \% \mathrm{Cl})$ \\
\hline & Santo Domingo & $14.6 \%$ & $8.8-20.4 \%$ & Observed $(95 \% \mathrm{Cl})$ \\
\hline \multirow{2}{*}{$\begin{array}{l}\text { Post-intervention percent } \\
\text { condom use per sex act }\end{array}$} & Puerto Plata & $28.8 \%$ & $21.5-36.4 \%$ & Observed $(95 \% \mathrm{Cl})$ \\
\hline & Santo Domingo & $17.6 \%$ & $11.7-23.5 \%$ & Observed $(95 \% \mathrm{Cl})$ \\
\hline \multirow{2}{*}{$\begin{array}{l}\text { Pre-intervention average } \\
\text { number of sex acts per } \\
\text { partner }\end{array}$} & Puerto Plata & 50.7 & $24-80$ & Estimated \\
\hline & Santo Domingo & 41.7 & $20-64$ & Estimated \\
\hline \multirow{2}{*}{$\begin{array}{l}\text { Average number of sex } \\
\text { partners for males (pre- } \\
\text { and post-intervention) }\end{array}$} & Puerto Plata & 3 & $2-4$ & Estimated \\
\hline & Santo Domingo & 3 & $2-4$ & Estimated \\
\hline \multirow{2}{*}{$\begin{array}{l}\text { Average number of sex } \\
\text { partners for females } \\
\text { (pre- and post- } \\
\text { intervention) }\end{array}$} & Puerto Plata & 5 & $2.8-7.2$ & Observed $(95 \% \mathrm{Cl})$ \\
\hline & Santo Domingo & 3 & $1.7-4.3$ & Observed $(95 \% \mathrm{Cl})$ \\
\hline \multicolumn{5}{|l|}{ For new paying clients } \\
\hline \multirow{2}{*}{$\begin{array}{l}\text { Pre-intervention: percent } \\
\text { condom use per sex act }\end{array}$} & Puerto Plata & $96.5 \%$ & $93.1-99.9 \%$ & Observed $(95 \% \mathrm{Cl})$ \\
\hline & Santo Domingo & $75.3 \%$ & $66.3-84.2 \%$ & Observed $(95 \% \mathrm{Cl})$ \\
\hline \multirow{2}{*}{$\begin{array}{l}\text { Post-intervention: } \\
\text { percent condom use per } \\
\text { sex act }\end{array}$} & Puerto Plata & $98.6 \%$ & $96.6-99.9 \%$ & Observed $(95 \% \mathrm{Cl})$ \\
\hline & Santo Domingo & $93.8 \%$ & $89.6-98.3 \%$ & Observed $(95 \% \mathrm{Cl})$ \\
\hline \multirow{2}{*}{$\begin{array}{l}\text { Pre-intervention average } \\
\text { number of sex acts per } \\
\text { partner }\end{array}$} & Puerto Plata & 2 & $1-3$ & Estimated \\
\hline & Santo Domingo & 2 & $1-3$ & Estimated \\
\hline \multirow[t]{2}{*}{$\begin{array}{l}\text { Average number of sex } \\
\text { partners for males (pre- } \\
\text { and post-intervention) }\end{array}$} & Puerto Plata & 11.4 & $4.9-19.5$ & $\begin{array}{l}\text { Estimated: low } 12.5 \% \\
\text { of female (39), med } \\
25 \% \text {, and high } 50 \%\end{array}$ \\
\hline & Santo Domingo & 5.88 & $2.5-10$ & $\begin{array}{l}\text { Estimated: low } 12.5 \% \\
\text { of female (20), med } \\
25 \% \text {, and high } 50 \%\end{array}$ \\
\hline \multirow{2}{*}{$\begin{array}{l}\text { Average number of sex } \\
\text { partners for females } \\
\text { (pre- and post- } \\
\text { intervention) }\end{array}$} & Puerto Plata & 39 & $22-56$ & Observed $(95 \% \mathrm{Cl})$ \\
\hline & Santo Domingo & 20 & $11-29$ & Observed $(95 \% \mathrm{Cl})$ \\
\hline
\end{tabular}


Economic. The cost per client to provide the environmental-structural intervention and the associated percentage of total costs are shown in Table 8 . Note that by design the intervention model was very similar in each city, and each intervention operated under a similar budget. However, in Puerto Plata the government health authorities enhanced their regulatory approach using existing resources as described earlier. Because the economic perspective taken in this analysis is that of the implementing NGO, the costs do not vary significantly across cities. These data on the cost of the intervention come from detailed cost worksheets that were completed by managers at each site and from ongoing consultation with NGO managers. The cost worksheets were compared to budgets and were reviewed and discussed with project team members to refine the estimates and to ensure that no research costs were included. The detailed cost estimates were collapsed into the categories shown, and ranges 25 percent above and below each cost category were included for sensitivity analysis. 
Table 8 Base-case values for economic parameters per female sex worker per year

\begin{tabular}{|c|c|c|c|c|c|}
\hline Parameter & Site & $\begin{array}{l}\text { Base-case } \\
\text { estimate }\end{array}$ & $\begin{array}{c}\text { Percent of } \\
\text { total } \\
\text { costs } \\
\end{array}$ & Range estimates & Data source \\
\hline \multirow[t]{2}{*}{$\begin{array}{l}\text { Administrative } \\
\& \text { infrastructure } \\
\text { costs }\end{array}$} & $\begin{array}{l}\text { Puerto } \\
\text { Plata }\end{array}$ & $\$ 14.38$ & 9.0 & $\$ 10.78-\$ 17.97$ & $\begin{array}{l}\text { Observed } \\
\text { (Range +/- 25\%) }\end{array}$ \\
\hline & $\begin{array}{l}\text { Santo } \\
\text { Domingo }\end{array}$ & $\$ 14.38$ & 8.8 & $\$ 10.78-\$ 17.97$ & $\begin{array}{l}\text { Observed } \\
\text { (Range +/- 25\%) }\end{array}$ \\
\hline \multirow[t]{2}{*}{ Training costs } & $\begin{array}{l}\text { Puerto } \\
\text { Plata }\end{array}$ & $\$ 5.88$ & 3.7 & $\$ 4.41-\$ 7.35$ & $\begin{array}{l}\text { Observed } \\
\text { (Range +/- 25\%) }\end{array}$ \\
\hline & $\begin{array}{l}\text { Santo } \\
\text { Domingo }\end{array}$ & $\$ 5.88$ & 3.6 & $\$ 4.41-\$ 7.35$ & $\begin{array}{l}\text { Observed } \\
\text { (Range +/- 25\%) }\end{array}$ \\
\hline \multirow[t]{2}{*}{ Labor } & $\begin{array}{l}\text { Puerto } \\
\text { Plata }\end{array}$ & $\$ 96.23$ & 60.3 & $\$ 72.18-\$ 120.29$ & $\begin{array}{l}\text { Observed } \\
\text { (Range +/- 25\%) }\end{array}$ \\
\hline & $\begin{array}{l}\text { Santo } \\
\text { Domingo }\end{array}$ & $\$ 100.85$ & 61.4 & $\$ 75.64-\$ 126.06$ & $\begin{array}{l}\text { Observed } \\
\text { (Range +/- 25\%) }\end{array}$ \\
\hline \multirow[t]{2}{*}{$\begin{array}{l}\text { Workshops } \\
\text { and theater }\end{array}$} & $\begin{array}{l}\text { Puerto } \\
\text { Plata }\end{array}$ & $\$ 18.15$ & 11.6 & $\$ 13.61-\$ 22.69$ & $\begin{array}{l}\text { Observed } \\
\text { (Range +/- 25\%) }\end{array}$ \\
\hline & $\begin{array}{l}\text { Santo } \\
\text { Domingo }\end{array}$ & $\$ 18.15$ & 11.1 & $\$ 13.61-\$ 22.69$ & $\begin{array}{l}\text { Observed } \\
\text { (Range +/- 25\%) }\end{array}$ \\
\hline \multirow{2}{*}{$\begin{array}{l}\text { Commodities } \\
\text { (condoms \& } \\
\text { educational } \\
\text { materials) }\end{array}$} & $\begin{array}{l}\text { Puerto } \\
\text { Plata }\end{array}$ & $\$ 24.91$ & 15.6 & $\$ 18.68-\$ 31.13$ & $\begin{array}{l}\text { Observed } \\
\text { (Range +/- 25\%) }\end{array}$ \\
\hline & $\begin{array}{l}\text { Santo } \\
\text { Domingo }\end{array}$ & $\$ 24.91$ & 15.2 & $\$ 18.68-\$ 31.13$ & $\begin{array}{l}\text { Observed } \\
\text { (Range +/- 25\%) }\end{array}$ \\
\hline \multirow[t]{2}{*}{$\begin{array}{l}\text { Total cost per } \\
\text { client }\end{array}$} & $\begin{array}{l}\text { Puerto } \\
\text { Plata }\end{array}$ & $\$ 159.55$ & 100.0 & $\$ 119.66-\$ 199.94$ & $\begin{array}{l}\text { Sum of values } \\
\text { Above }\end{array}$ \\
\hline & $\begin{array}{l}\text { Santo } \\
\text { Domingo }\end{array}$ & $\$ 164.17$ & 100.0 & $\$ 123.13-\$ 205.21$ & $\begin{array}{l}\text { Sum of values } \\
\text { Above }\end{array}$ \\
\hline
\end{tabular}




\section{Results}

\section{Base-case outcomes}

Base-case cost-effectiveness results are shown in year 2001 U.S. dollars (rounded to the nearest dollar) and presented in terms of a program that would reach 10,000 clients per city (Table 9). In Puerto Plata, with enhanced government regulations in place, the intervention is estimated to avert 162 HIV infections among 10,000 clients reached: 142 among female sex workers, two among new male clients, and 19 among regular sexual partners. In contrast, in Santo Domingo, the intervention is estimated to avert 64 HIV infections: 54 among female sex workers, two among new clients, and eight among regular partners.

It is noteworthy that the intervention has its largest impact on HIV transmission to female sex workers. Among men, it is the regular partners of sex workers, rather than their new clients, who are most likely to benefit from the intervention. Moreover, the intervention model implemented in Puerto Plata that included government policy and regulation averted 2.5 times more infections, than the model implemented in Santo Domingo. As a result, the cost per HIV infection averted in Puerto Plata, at $\$ 9,843$, is significantly less than in Santo Domingo, at $\$ 25,574$. Thus, the cost per DALY is \$414 in Puerto Plata vs. \$1,075 in Santo Domingo.

\section{Table 9 Base-case 1-year cost-effectiveness of $100 \%$ condom intervention per} 10,000 clients

\begin{tabular}{|c|c|c|}
\hline & Puerto Plata & Santo Domingo \\
\hline \multirow{2}{*}{$\begin{array}{l}\text { HIV infections } \\
\text { averted }\end{array}$} & 162 & 64 \\
\hline & $\begin{array}{l}\text { - } 141 \text { among females } \\
\text { - } 2 \text { among new male partners } \\
\text { - } 19 \text { among regular male partners }\end{array}$ & $\begin{array}{l}\text { - } 54 \text { among females } \\
\text { - } 2 \text { among new male partners } \\
\text { - } 8 \text { among regular male partners }\end{array}$ \\
\hline $\begin{array}{l}\text { Cost per HIV } \\
\text { infection averted, } \\
\text { Puerto Plata }\end{array}$ & $\$ 9,843$ & $\$ 25,574$ \\
\hline $\begin{array}{l}\text { Cost per DALY } \\
\text { saved, } \\
\text { Santo Domingo }\end{array}$ & $\$ 414$ & $\$ 1,075$ \\
\hline
\end{tabular}

\section{Sensitivity analysis: one-way analysis}

Results of the one-way sensitivity analysis are shown, indicating the impact of variation of individual model parameters on the cost per DALY saved in each city (Table 10). In both Puerto Plata and Santo Domingo the cost per DALY saved is most sensitive to the discount rate, HIV prevalence, the estimated DALYs saved per HIV infection averted, and the contact rate between female sex workers and regular partners. The discount rate is an adjustment made in the analysis 


\section{Hgrizons}

that gives reduced weight to future rather than current health benefits for economic investments in health. For example, if we value long-term benefits equally to short-term benefits (e.g., a discount rate of 0 percent), the cost per DALY saved in Puerto Plata is reduced from the base-case value of $\$ 414$ to $\$ 178$.

The 3 percent discount rate used in the base-case analysis is a standard frequently used in costeffectiveness analyses. The cost-effectiveness of the 100 percent condom intervention is shown to be strongly related to the HIV prevalence of the target population and their sexual partners, and the cost per DALY saved is affected by changes in the number of saved life years associated with each averted infection. In one-way analysis it was also found that the cost-effectiveness of the intervention was sensitive to the number of regular partners each female sex worker has, as well as the frequency of sexual contact with regular partners. 
Table 10 One-way sensitivity analysis

\begin{tabular}{|c|c|c|c|}
\hline \multicolumn{2}{|c|}{ One-way sensitivity analysis } & \multicolumn{2}{|c|}{$\begin{array}{c}\text { Average cost per DALY } \\
\text { saved (\$USD / 2001) }\end{array}$} \\
\hline & & $\begin{array}{l}\text { Puerto } \\
\text { Plata }\end{array}$ & $\begin{array}{l}\text { Santo } \\
\text { Domingo }\end{array}$ \\
\hline \multicolumn{2}{|c|}{ Base-case (see previous tables for base-case values and ranges) } & $\$ 414$ & $\$ 1,075$ \\
\hline \multirow[t]{2}{*}{ Discount rate } & $0 \%$ Discounting & $\$ 178$ & $\$ 463$ \\
\hline & $6 \%$ Discounting & $\$ 854$ & $\$ 2,219$ \\
\hline \multirow{2}{*}{$\begin{array}{l}\text { HIV infectivity (infectivity } \\
\text { adjusted for gender and } \\
\text { STI prevalence) }\end{array}$} & $33 \%$ Decrease from base-case & $\$ 578$ & $\$ 1,532$ \\
\hline & $33 \%$ Increase from base-case & $\$ 334$ & $\$ 846$ \\
\hline \multirow{2}{*}{$\begin{array}{l}\text { Number of regular sex } \\
\text { partners }\end{array}$} & Upper bound of observed $95 \% \mathrm{Cl}$ & $\$ 289$ & $\$ 807$ \\
\hline & Lower bound of observed $95 \% \mathrm{Cl}$ & $\$ 713$ & $\$ 1,560$ \\
\hline \multirow{2}{*}{$\begin{array}{l}\text { Number of sex acts with } \\
\text { regular partners }\end{array}$} & Upper bound of observed $95 \% \mathrm{Cl}$ & $\$ 309$ & $\$ 850$ \\
\hline & Lower bound of observed $95 \% \mathrm{Cl}$ & $\$ 727$ & $\$ 1,577$ \\
\hline \multirow{2}{*}{$\begin{array}{l}\text { Condom use with regular } \\
\text { partners }\end{array}$} & Upper bound of observed $95 \% \mathrm{Cl}$ & $\$ 498$ & $\$ 1,408$ \\
\hline & Lower bound of observed $95 \% \mathrm{Cl}$ & $\$ 355$ & $\$ 872$ \\
\hline \multirow{2}{*}{$\begin{array}{l}\text { Number of new sex } \\
\text { partners }\end{array}$} & Upper bound of observed $95 \% \mathrm{Cl}$ & $\$ 384$ & $\$ 814$ \\
\hline & Lower bound of observed $95 \% \mathrm{Cl}$ & $\$ 427$ & $\$ 1,279$ \\
\hline \multirow{2}{*}{$\begin{array}{l}\text { Number of sex acts with } \\
\text { new partners }\end{array}$} & Upper bound of observed $95 \% \mathrm{Cl}$ & $\$ 402$ & $\$ 931$ \\
\hline & Lower bound of observed $95 \% \mathrm{Cl}$ & $\$ 426$ & $\$ 1,273$ \\
\hline \multirow{2}{*}{$\begin{array}{l}\text { Condom use with new } \\
\text { partners }\end{array}$} & Upper bound of observed $95 \% \mathrm{Cl}$ & $\$ 434$ & $\$ 1,238$ \\
\hline & Lower bound of observed $95 \% \mathrm{Cl}$ & $\$ 396$ & $\$ 950$ \\
\hline \multirow[t]{2}{*}{ HIV prevalence } & $33 \%$ Increase from base-case & $\$ 290$ & $\$ 737$ \\
\hline & $33 \%$ Decrease from base-case & $\$ 708$ & $\$ 1,886$ \\
\hline \multirow[t]{2}{*}{ Cost per client } & $33 \%$ Increase from base-case & $\$ 550$ & $\$ 1,430$ \\
\hline & $33 \%$ Decrease from base-case & $\$ 277$ & $\$ 720$ \\
\hline \multirow{2}{*}{$\begin{array}{l}\text { DALYs saved per HIV } \\
\text { infection averted }\end{array}$} & $33 \%$ Increase from base-case & $\$ 311$ & $\$ 809$ \\
\hline & $33 \%$ Decrease from base-case & $\$ 618$ & $\$ 1,605$ \\
\hline
\end{tabular}

\section{Sensitivity analysis: multi-way analysis}

Worst and best case scenarios are presented, where all model parameters are set for the least and most cost-effective outcome, respectively (Table 11; Figures 2 and 3). The best and worst case scenarios also convey the level of uncertainty incumbent in the model. 


\section{Hgrizons}

In the worst case scenario, the cost per DALY saved goes from the base-case of $\$ 414$ in Puerto Plata and \$1,025 in Santo Domingo, to \$1,194 and \$6,202, respectively. In the best case scenario, the cost per DALY saved is reduced to \$139 in Puerto Plata and \$264 in Santo Domingo. We examined the sensitivity of combinations of several of the important model parameters from the one-way analysis and found that what accounts for most of the estimate variance is the combination of the discount rate and the HIV infectivity, both parameters that are based on estimates from the literature, as is the case with most such models. In three-way analyses we see, again, that the economic and epidemiologic parameters in combination affect the model outcome much more than the behavioral data, which was collected directly from the study and which has much less uncertainty given our ability to generate 95 percent confidence intervals used for sensitivity analysis. Finally, we conducted a multivariate sensitivity analysis by regressing the results of the iterations of the stochastic model. This is an especially valuable analysis because model parameters frequently covary, and the multivariate analysis shows the independent effect of model parameters on the outcome.

The results in Puerto Plata and Santo Domingo are similar, with the most sensitive model parameters being the discount rate and HIV prevalence. In Santo Domingo, the rate of STI infection was also shown to have a strong independent effect on the cost per DALY saved. Additionally, in both cities there are strong effects on the cost-effectiveness of the intervention based on the pre-intervention sexual contact rates with regular sexual partners, especially when the partner is HIV-positive. Interestingly, variation in the cost of the intervention has only a moderate impact on the cost-effectiveness of the intervention, compared to epidemiologic and behavioral model parameters. 
Table 11 Multi-way sensitivity analysis

\begin{tabular}{|c|c|c|c|}
\hline & & \multicolumn{2}{|c|}{$\begin{array}{l}\text { Average cost per DALY } \\
\text { saved (\$USD / 2001) }\end{array}$} \\
\hline & & $\begin{array}{l}\text { Puerto } \\
\text { Plata }\end{array}$ & $\begin{array}{l}\text { Santo } \\
\text { Domingo }\end{array}$ \\
\hline \multicolumn{2}{|l|}{ Base-case } & $\$ 414$ & $\$ 1,075$ \\
\hline \multicolumn{2}{|c|}{$\begin{array}{l}\text { Worst-case scenario (all parameter values set for worst } \\
\text { case) }\end{array}$} & $\$ 1,194$ & $\$ 6,202$ \\
\hline \multicolumn{2}{|c|}{ Best-case scenario (all parameter values set for best case) } & $\$ 139$ & $\$ 264$ \\
\hline \multicolumn{4}{|l|}{ Two-way sensitivity analysis } \\
\hline \multirow[t]{2}{*}{$\begin{array}{l}\text { (1) Discount rate by (2) HIV } \\
\text { infectivity }\end{array}$} & $\begin{array}{l}\text { Worst case (low } \\
\text { discount/low infectivity) }\end{array}$ & $\$ 1,133$ & $\$ 3,423$ \\
\hline & $\begin{array}{l}\text { Best case (high } \\
\text { discount/low infectivity) }\end{array}$ & $\$ 251$ & $\$ 533$ \\
\hline \multirow{2}{*}{$\begin{array}{l}\text { (1) Number of regular } \\
\text { partners by (2) post- } \\
\text { intervention condom use } \\
\text { with regular partners }\end{array}$} & $\begin{array}{l}\text { Worst case (low regular } \\
\text { partner/low condom use) }\end{array}$ & $\$ 719$ & $\$ 1,552$ \\
\hline & $\begin{array}{l}\text { Best case (high regular } \\
\text { partner/high condom) }\end{array}$ & $\$ 283$ & $\$ 819$ \\
\hline \multirow[t]{2}{*}{$\begin{array}{l}\text { (1) HIV prevalence by (2) } \\
\text { number of new partners }\end{array}$} & $\begin{array}{l}\text { Worst case (low } \\
\text { prevalence/low \# partners) }\end{array}$ & $\$ 694$ & $\$ 1,838$ \\
\hline & $\begin{array}{l}\text { Best case (high } \\
\text { prevalence/low \# partners) }\end{array}$ & $\$ 287$ & $\$ 740$ \\
\hline \multicolumn{4}{|l|}{ Three-way analyses } \\
\hline \multirow{2}{*}{$\begin{array}{l}\text { Economic \& epidemiologic: } \\
\text { (1) intervention cost by (2) } \\
\text { DALY per HIV infection } \\
\text { averted by (3) HIV } \\
\text { infectivity }\end{array}$} & $\begin{array}{l}\text { Worst case (high cost/low } \\
\text { DALY/low infectivity) }\end{array}$ & $\$ 1,498$ & $\$ 3,998$ \\
\hline & $\begin{array}{l}\text { Best case (low cost/high } \\
\text { DALY/high infectivity) }\end{array}$ & $\$ 133$ & $\$ 345$ \\
\hline \multirow[t]{2}{*}{$\begin{array}{l}\text { Behavioral: ( } 1 \text { ) condom } \\
\text { percentage by }(2) \text { number } \\
\text { of regular partners by }(3) \\
\text { number of sexual acts }\end{array}$} & $\begin{array}{l}\text { Worst case (low } \\
\text { condom/low \# regular } \\
\text { partners/low sex acts) }\end{array}$ & $\$ 1,037$ & $\$ 1,922$ \\
\hline & $\begin{array}{l}\text { Best case (high } \\
\text { condom/high \# regular } \\
\text { partners/high low sex acts) }\end{array}$ & $\$ 234$ & $\$ 633$ \\
\hline
\end{tabular}


Table 11 continued: Multivariate Sensitivity Analysis - Regression Model - Association between model parameters and average cost per DALY averted. (Standardized Beta coefficients greater than 0.10 shown)

Santo Domingo. $\mathrm{R}^{2}=0.83$. (1) Discount rate [0.56], (2) HIV prevalence [-0.34], (3) Baseline non-GUD [-0.33], (4) Post-intervention non-GUD [0.29], (5) Pre-intervention number of sex acts with regular partners of HIV+ women [-0.21], (6) Pre-intervention condom use with regular partners of HIV + women [0.20], (7) Post-intervention condom use with regular partners of HIV + women [-0.18], (8) Pre-intervention number of sex partners with regular partners of HIV- women [-0.17], (9) Labor costs [0.11], (10) Pre-intervention number of sex acts with new clients of HIV+ women [-0.11], (11) Pre-intervention condom use with new clients of HIV+ women [0.10].

Puerto Plata. $R^{2}=0.89$. (1) Discount rate [0.64], (2) HIV Prev [-0.38], (3) Pre-intervention number of sex acts with regular partners of HIV + women [-0.35], (4) Pre-intervention number of sex partners with regular partners of HIV + women [-0.30], (5) Baseline non-GUD [-0.24], (6) Post-intervention non-GUD [0.19], (7) Pre-intervention condom use with regular partners of HIV + women [0.15], (8) Post-intervention condom use with regular partners of HIV+ women [-0.15], (9) Labor costs [0.12].

Figure 2 Regression sensitivity analysis: Puerto Plata

Discount rate

HIV prevalence

Pre-intv \# sex acts among HIV+ reg partners

Pre-intv \# sex partners among HIV- reg partners

Pre-intv non-GUD among sex workers

Post-intv non-GUD among sex workers

Pre-intv condom use w/HIV+ regular partners

Pre-intv condom use w/HIV+ regular partners

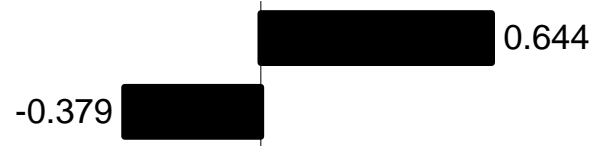

$-0.349$

$-0.299$

$-0.237$

0.187

0.154

Labor costs

$-0.151$

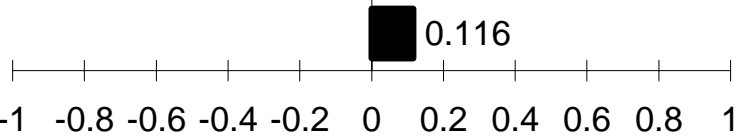

Std b Coefficients 
Figure 3 Regression sensitivity analysis: Santo Domingo

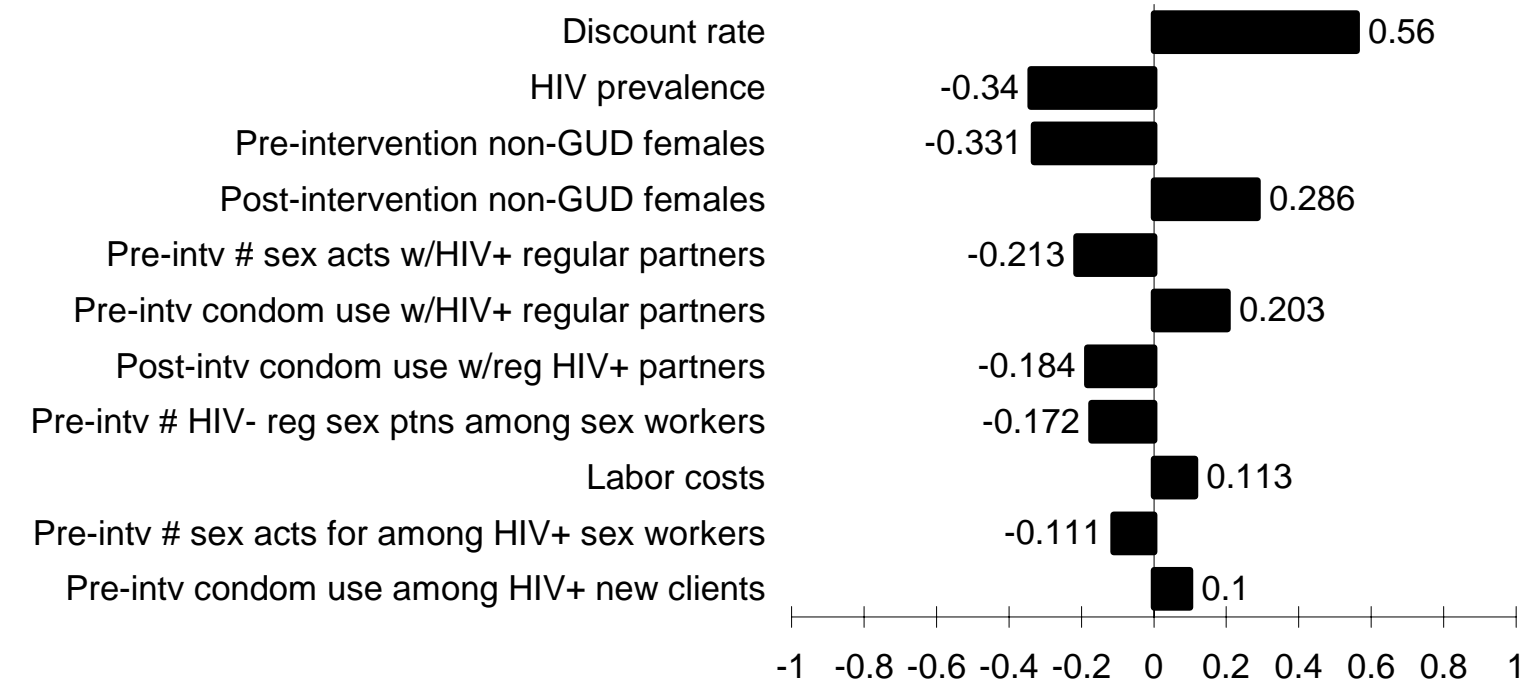

Std b Coefficients 


\section{Hgrizons}

\section{Discussion}

Interest in environmental-structural interventions as effective strategies to prevent HIV/STI has increased steadily over recent years. However, despite increased interest and discourse, there have been limited data available documenting the relationships between environmental-structural interventions and specific reductions in HIV-related risk. Additionally, the transferability of "successful" environmental-structural interventions has not been well evaluated and/or documented in the literature (Parker et al. 2000). The current research helps to fill such knowledge gaps by demonstrating the feasibility and effectiveness of a culturally appropriate adaptation of the Thai 100 percent condom program, widely recognized as an effective environmental-structural HIV prevention intervention, in the female sex industry of the Dominican Republic.

With both intervention models implemented, we found statistically significant changes were documented pre- to post-intervention for all three of the study's outcomes: consistent condom use, ability to verbally reject unsafe sex, and STI prevalence rates in both cities. However, the type and level of these changes varied by intervention approach. For example, statistically significant increases were documented with new clients in Santo Domingo, while significant increases were found with regular paying and non-paying partners in the last month in Puerto Plata only. Such changes in condom use with regular partners in the last month are particularly important given the significantly lower levels of pre-intervention condom use documented by the study in these situations, compared to condom use with new clients. Additionally these increases take on additional importance, given that the majority of sexual interactions among participating sex workers appear to be taking place with repeat or regular paying partners, based on the number of client dates reported in the last week and the median number of total sex partners reported per month.

For both intervention models, significant reductions in STI were documented over the course of the intervention, while reductions documented were slightly stronger in Puerto Plata. Additionally, only in Puerto Plata were significant pre- to post-intervention increases found in participating sex workers' observed verbal ability to reject unsafe commercial sex. The triangulation of findings indicate that while in both cities the models implemented may have had a positive impact on reducing HIV-related vulnerability among participating sex workers, the impact of the intervention appears to have been more broad-based in Puerto Plata, where both solidarity and policy intervention approaches were combined.

The pathway by which these additional gains were achieved in Puerto Plata appears to be linked to the ability of the combined solidarity-plus-government-policy model to achieve higher levels of compliance with intervention elements. For example, in bivariate analysis, exposure and compliance with the intervention have independent, significant associations with consistent condom use with all partners in the last month, as does the variable city. When fitting the final multivariate model, however, we find that the significant effect of city fades only when the observed level compliance with the intervention is added to the model. These findings suggest that in places where higher levels of compliance can be achieved, comparable increases in condom use 
may be possible, regardless of geographic location. However, the study also found that it was in Puerto Plata only where such levels of intense adoption or compliance with key intervention elements were documented.

The cost-effectiveness analysis provides valuable insights into the feasibility and relative advantage of adoption of these competing intervention models. A clear result of this analysis was that it is significantly more cost-effective to adopt the combined intervention model that includes the governmental regulation and oversight. Our cost analysis revealed that the cost to implement the two intervention models is comparable, yet with enhanced regulation by preexisting government health authorities, the intervention is more than two and a half times more cost-effective. We also found that at $\$ 414$ per disability adjusted life year saved, the intervention as conducted in Puerto Plata is a reasonably cost-effective investment in reducing the burden of HIV/AIDS disease in the Dominican Republic.

These results were robust over a wide range of assumptions. While data on the cost of treatment are scarce, it is also reasonable to assume that the intervention is also cost saving in this area. For example, the threshold for the lifetime treatment cost for HIV/AIDS would only have to be $\$ 9,843$ before the savings resulting from the intervention would produce a cost savings in medical costs alone. Sensitivity analysis revealed that several factors enhance the cost-effectiveness significantly, including implementing the intervention in geographic settings with higher rates of HIV prevalence among the target population, especially where condom use is low among regular partners of female sex workers. Both models of the intervention are also arguably cost-effective compared to others found in the literature in similar settings.

Based on our findings, program planners and policy makers involved in the study in the Dominican Republic agree that the integrated solidarity and policy model in conjunction with ongoing peer education and community mobilization activities is an appropriate, cost-effective, and ethical intervention package. This study's findings, however, do not necessarily answer that question for other countries. Each country and community must examine how a community-based solidarity approach and/or a government-sponsored, policy-based approach will be received and function in their own practical and political realities.

Yet the study findings offer evidence that environmental-structural interventions that seek to enable and promote individual as well as collective efficacy to prevent HIV are important, effective, and ethical options to consider. Furthermore, the experience of the Dominican Republic in adapting the Thai 100 percent condom model demonstrates that government policy initiatives to prevent HIV in the realm of female sex work do not have to be top-down, lack community participation, or infringe upon the human rights of sex workers (Loff et al. 2003), concerns voiced by members of both the activist and research communities. Instead, government policy can help to support community members and the efforts of grassroots NGOs when all of these actors participate in its construction, implementation and evaluation.

The current dialogue is now focused on how to scale up this successful pilot experience in a way that continues to respect all members of the sex work community and to be effective in curbing the HIV epidemic. An added component of any program scale up will surely include a more intense set 


\section{Hgrizons}

of intervention activities involving the male clients of female sex workers. Participating sex workers from the current study who tested positive for STIs at both pre- and post-test were asked, in a brief open-ended questionnaire as part of post-test counseling, how the intervention could help support them to avoid reinfection. Almost unanimously the women stated that future intervention efforts must increase the reach and scope of work with male clients. Additionally, most women articulated the importance of special efforts to involve both regular paying and non-paying partners of female sex workers, by whom many of the women felt they had been infected. Currently, formative ethnographic research is under way in the Dominican Republic to understand how to engage male clients and mobilize their potential to prevent HIV. 


\section{Limitations of the Research}

One limitation of the study is that the pre-test/post-test research design limits our ability to establish causal associations. Specifically, with regard to changes in HIV-risk pre- to postintervention, the current research cannot fully establish whether the changes that occurred and/or the associations found between higher levels of exposure to and compliance with the intervention and consistent condom use are the result of the intervention. However, in an effort to address limitations of the study design, triangulation of data collection for study outcomes and serial crosssectional data establishing temporal trends were utilized.

The internal consistency across all three study outcomes (e.g., reported consistent condom use, observed ability to reject unsafe sex, and results of STI testing) corroborate that significant improvements, particularly in the case of Puerto Plata, were achieved from pre- to postintervention. Additionally, serial cross-sectional data on exposure and compliance helps to illuminate the mechanism by which the intervention models may have had an effect on reducing the vulnerability of sex workers to HIV infection. In addition to implementation of the solidarity and solidarity plus policy arms, the study design may have been strengthened by including an intervention arm consisting of only government policy and regulation. However, none of the institutions involved in the study believed government policy and regulation alone to be an ethical intervention strategy, given the conceptual and programmatic importance and success of almost 15 years of community empowerment and mobilization efforts among female sex workers in the Dominican context. 


\section{Hgrizons}

\section{Conclusions}

Both of the adapted 100 percent condom models implemented as part of this study in the Dominican Republic had a positive impact on specific HIV-related outcomes. However, findings suggest that an integrated model involving both a community-based solidarity approach and a government-sponsored policy and regulation approach focused on HIV prevention and condom use led to further increases in HIV-related protective behavior as well as reductions in STI among female sex workers. It was also significantly more cost-effective. However, in order to achieve sustainable programmatic success, environmental-structural interventions must engage community members in the conceptualization, implementation and evaluation of policy-based initiatives to ensure both their effectiveness as well as their acceptability and appropriateness in reducing HIV-related risk in the context of female sex work. 


\section{References}

Aggleton, Peter. 1997. "Behavior change communication strategies," AIDS Education and Prevention 9(2): 111-123.

AIDSCAP/FHI.“ 1993. Technical Assessment of AIDS in the Dominican Republic: A Report to the U.S. Agency for International Development." Santo Domingo: AIDSCAP/FHI.

Aklilu, Mathias et al. 2001. "Factors associated with HIV-1 infection among sex workers of Addis Ababa, Ethiopia," AIDS 15: 87-96.

Asamoah-Adu, Comfort et al. 2001. "HIV Infection Among Sex Workers in Accra: Need to Target New Recruits Entering the Trade," Journal of Acquired Immune Deficiency Syndromes 28: 358366.

Auerbach, Judith D. and Thomas J. Coates. 2000. "HIV prevention research: accomplishments and challenges for the third decade of AIDS," American Journal of Public Health 90(7): 1029-1032.

Bhave, G. et al. 1995. "Impact of an intervention on HIV, sexually transmitted diseases, and condom use among sex workers in Bombay, India," AIDS 9 (Suppl 1): S21-30.

Busza, Joanne and B.T. Schunter. 2001. "From competition to community: participatory learning and action among young, debt-bonded Vietnamese sex workers in Cambodia," Reproductive Health Matters 9(17): 72-81.

Campbell, Catherine. 2000. "Selling sex in the time of AIDS: the psycho-social context of condom use by sex workers on a Southern African mine," Social Science \& Medicine 50(4): 479-94.

Campbell, Catherine and Zodwa Mzaidume. 2001. "Grassroots participation, peer education, and HIV prevention by sex workers in South Africa," American Journal of Public Health 91(12): 19781986.

Celentano, David D. et al. 1998. "Decreasing incidence of HIV and sexually transmitted diseases in young Thai men: evidence for success of the HIV/AIDS control and prevention program," AIDS 12(5): 29-36.

CESDEM (Centro de Estudios Sociales y Demograficos). 1996. "Informe de Resultados. Encuesta sobre Conocimientos, Creencias, Actitudes y Prácticas acerca del VIH/SIDA en Trabajadoras Sexuales y Hombres Involucrados en La Industria del Sexo en Santo Domingo" [Final Report. Survey of knowledge, beliefs, attitudes and practices in relation to HIV/AIDS among Female Sex Workers and Men Involved in the sex industry in the Dominican Republic], Santo Domingo: CESDEM. 


\section{Hgrizons}

1999. "Informe de Resultados. Encuesta sobre Conocimientos, Creencias, Actitudes y

Prácticas acerca del VIH/SIDA en Trabajadoras Sexuales y Hombres Involucrados en La Industria del Sexo de la República Dominicana" [Final Report. Survey of knowledge, beliefs, attitudes and practices in relation to HIV/AIDS among Female Sex Workers and Men Involved in the sex industry in the Dominican Republic], Santo Domingo: CESDEM.

2003. Encuesta Demografica y de Salud 2002: Informe Preliminar sobre VIH/SIDA. [Demographic Health Survey 2002: preliminary results regarding HIV/AIDS]. Santo Domingo: CESDEM.

COIN (Centro de Orientacion e Investigacion Integral). 1998. "Census of commercial sex establishments," Santo Domingo: COIN.

- 2000. Personal communication. Santo Domingo.

DIGECITSS (Dirección General del Control de las Enfermedades de Transmisión Sexual y SIDA. 2000. "Vigilancia Centinela de la Infección VIH. Informe de Monitoreo 10 mo. año" [Sentinel Surveillance of HIV Infection. Monitoring report from 10th year], Santo Domingo: SESPAS.

Evans, Catherine. 1999. "An international review of the rationale, role and evaluation of community development approaches in interventions to reduce HIV transmission in sex work," Horizons Program Report. New Delhi: Population Council.

Ford, Kathleen et al. 1996. "Behavioral interventions for reduction of sexually transmitted disease/HIV transmission among female commercial sex workers and clients in Bali, Indonesia," AIDS 10(2): 213-222.

Futures Group. 2002. Documenting the experience of sex workers. Report to the Future's Group Policy Project from David Lowe Consulting/Asia. Washington, D.C.: Futures Group.

Ghys, Peter D. et al. 2001. "Effect of interventions to control sexually transmitted disease on the incidence of HIV infection in female sex workers," AIDS 15: 1421-1431.

Gray, Jennifer A. et al. 1997. "HIV-1 infection among female commercial sex workers in rural Thailand," AIDS 11(1): 89-94.

Gysels, Marjolein, Robert Pool, and Betty Nnalusiba. 2002. "Women who sell sex in a Ugandan trading town: life histories, survival strategies and risk," Social Science and Medicine 54(2): 179192.

Hanenberg, Robert S. et al. 1994. "Impact of Thailand's HIV-control programme as indicated by the decline of sexually transmitted diseases," Lancet 344(8917): 243-245. 
Hendriks, J.C. et al. 1996. "Estimation of progression of HIV infection among intravenous drug users using a death-included staged Markov model," paper presented at the $11^{\text {th }}$ International Conference on AIDS, Vancouver, Canada (Abstract no. Th.C.223).

Jana, Smarajit et al. 1998. "STD/HIV intervention with sex workers in West Bengal, India," AIDS 12 (Suppl B): S101-108.

Kalipeni, Ezekiel. 2000. "Health and disease in southern Africa: a comparative and vulnerability perspective," Social Science \& Medicine 50(7-8): 965-983.

Kerrigan, Deanna. 2000. "Individual, Relational, and Environmental-Structural Determinants of Consistent Condom Use Among Female Sex Workers and their Regular Partners in the Dominican Republic," Doctoral Dissertation. Baltimore: Johns Hopkins School of Public Health.

Kerrigan, Deanna et al. 1997. "Formative Research for a 100\% Condom Program in the Dominican Republic," Santo Domingo: AIDSCAP/FHI/USAID.

Kerrigan, Deanna et al. 2001. "Adapting the Thai 100\% condom programme: developing a culturally appropriate model for the Dominican Republic," Culture, Health and Sexuality 3(2): 221-240.

Kilmarx, Peter H. et al. 1998. "HIV-1 seroconversion in a prospective study of female sex workers in northern Thailand: continued high incidence among brothel-based women," AIDS 12(14): 18891898.

Laga, Marie et al. 1994. "Condom promotion, sexually transmitted diseases treatment, and declining incidence of HIV-1 infection in female Zairian sex workers," Lancet 344(8917): 246-248.

Leonard, Lori, et al. 2001. "HIV prevention among male clients of female sex workers in Kaolack, Senegal: results of a peer education program," AIDS Education and Prevention 12(1):21-37.

Loff, Bebe, Cheryl Overs, and Paulo Longo. 2003. "Can health programmes lead to the mistreatment of sex workers?" Lancet 361(9373): 1982.

Mason, C.J. et al. 1995. "Declining prevalence of HIV-1 infection in young Thai men," AIDS 9(9): 1061-1065.

Mehendale, Sanjay M. et al. 1995. "Incidence and predictors of human immunodeficiency virus type 1 seroconversion in patients attending sexually transmitted disease clinics in India," Journal of Infectious Diseases 172(6): 1486-1491.

Merson, Michael H., J.M. Dayton, and Kevin O'Reilly. 2000. "Effectiveness of HIV prevention interventions in developing countries," AIDS 14(Suppl 2): S68-84. 


\section{Hgrizons}

Moreno, Luis and Deanne Kerrigan. 2000. "HIV Prevention strategies among female sex workers in the Dominican Republic," Research for Sex Work 3: 8-10.

Morisky, Donald et al. 2002. The impact of the work environment on condom use among female bar workers in the Philippines. Health Education and Behavior. Aug;29(4):461-72.

Morisky, Donald E. et al. 1998. "The effects of establishment practices, knowledge and attitudes on condom use among Filipina sex workers," AIDS Care 10(2): 213-220.

Murray, C. J. L. and A.D. Lopez. 1996. "The global burden of disease: a comprehensive assessment of mortality and disability from diseases, injuries, and risk factors in 1990 and projected to 2020," Cambridge: Harvard University Press.

Nelson, Kenrad E. et al. 1996. "Changes in sexual behavior and a decline in HIV infection among young men in Thailand," New England Journal of Medicine 335(5): 297-303.

Nelson, Kenrad E. et al. 2002. "HIV infection in young men in northern Thailand, 1991-1998: Increasing role of injection drug use," Journal of Acquired Immune Deficiency Syndrome 29(1): $62-68$

Ngugi, Elizabeth N. et al. 1996. "Focused peer-mediated educational programs among female sex workers to reduce sexually transmitted disease and human immunodeficiency virus transmission in Kenya and Zimbabwe," Journal of Infectious Diseases 174 (Suppl 2): S240-S247.

O'Reilly, Kevin R. and Peter Piot. 1996. "International perspectives on individual and community approaches to the prevention of sexually transmitted disease and human immunodeficiency virus infection," Journal of Infectious Diseases 174 (Suppl 2): S214-222.

Pareja, Reynaldo and Santo Rosario. 1992. "Sexo, Trabajo y Sociedad" [Sex, Work, and Society,] Santo Domingo: La Unión.

Parker, Richard et al. 2002. "HIV/AIDS-related stigma and discrimination: A conceptual framework and an agenda for action," Horizons report. Washington, D.C.: Population Council.

Parker, Richard F., D. Easton, and C.H. Klein. 2000. "Structural barriers and facilitators in HIV prevention: a review of international research," AIDS 14 (Suppl 1): S22-32.

Quan, Vu Minh et al. 2000. "HIV in Vietnam: the evolving epidemic and the prevention response, 1996 through 1999," Journal of Acquired Immune Deficiency Syndrome 25(4): 360-369.

Rehle, T. et al. 1998. "AVERT: A User Friendly Model to Estimate the Impact of HIV/Sexually Transmitted Disease Prevention Interventions on HIV Transmission,” AIDS 12: S27-S35.

Rojanapithayakorn, Wiwat and Robert Hanenberg. 1996. "The 100\% condom program in Thailand," AIDS 10(1): 1-7. 
Rosario, Santo et al. 1994. "La Industria de Sexo por Dentro," Santo Domingo: COIN.

Sakondhavat, Chuanchom et al. 1997. "Promoting condom-only brothels through solidarity and support for brothel managers," International Journal of STD and AIDS 8: 40-43.

Sumartojo, E. (ed.). 2000. "Structural factors and HIV prevention," AIDS 14 (Suppl 1): S3-S10.

Sweat, Michael and Julie Denison. 1995. "Reducing HIV incidence in developing countries with structural and environmental interventions," AIDS 9 (Suppl A): S251-S257.

Tawil, Oussama, A.Verster, and Kevin R. O'Reilly. 1995. "Enabling approaches for HIV/AIDS prevention: can we modify the environment and minimize the risk?" AIDS 9: 1299-1306.

Tiglao, Teodoro V. et al. 1996. "A community P.A.R. Approach to HIV/AIDS prevention among sex workers," Promotion and Education 3(4): 25-28.

- 2002. "Sex work and HIV/AIDS. Technical Update," UNAIDS Best Practice Collection. Geneva: UNAIDS.

UNFPA (United Nations Population Division). 2001. "World Population Prospects: The 2000 Revision Highlights," Population Division of the Department of Economic \& Social Affairs of the United Nations Secretariat.

Visrutaratna, S. 1995. “'Superstar' and 'model brothel': developing and evaluating a condom promotion program for sex establishments in Chiang Mai, Thailand," AIDS 9(Suppl 1): S69-75.

Waldo, Craig R. and Thomas J. Coates. 2000. "Multiple levels of analysis and intervention in HIV prevention science: exemplars and directions for new research," AIDS 14(Suppl 2): S18-26.

Weinstein, M. et al. 1989. "Cost-effectiveness analysis of AIDS prevention programs: concepts, complications, and illustrations," Washington, D.C.: National Academy Press.

World Bank. 1993. "World Development Report: Investing in Health," New York: Oxford University Press. 


\section{Hgrizons}

Horizons is a global operations research program designed to:

- Identify and test potential strategies to improve HIV/AIDS prevention, care, and support programs and service delivery.

- Disseminate best practices and utilize findings with a view toward scaling up successful interventions.

\section{(2) Population Council}

Horizons is implemented by the Population Council in collaboration with

- International Center for Research on Women (ICRW)

- International HIV/AIDS Alliance

- Program for Appropriate Technology in Health (PATH)

- Tulane University

- Family Health International (FHI)

- Johns Hopkins University

For more information, please contact:

Horizons Program, Communications Unit 4301 Connecticut Avenue, NW Suite 280 Washington, DC 20008 USA

Tel: 202-237-9400

Fax: 202-237-8410

Email: horizons@pcdc.org www.popcouncil.org/horizons 